\title{
Explaining Enterprise Performance in Developing Countries with Business Climate Survey Data
}

\section{Jean-Jacques Dethier • Maximilian Hirn • Stéphane Straub}

The authors survey the recent literature which examines the impact of the business climate on productivity and growth in developing countries using enterprise surveys. Comparable enterprise surveys today cover more than 100,000 firms in 123 countries. The literature that has analyzed this data provides evidence that a good business climate favors growth by encouraging investment and higher productivity. Various infrastructure, finance, security, competition, and regulation variables have been shown to have a significant impact on enterprise performance. The authors state their motivation for their review by explaining why a disaggregated, firm-level analysis of the relationship between enterprise performance and business climate-as opposed to a more macroaggregate analysis - is important to gaining insights into these issues. They review the main findings of the empirical microliterature based on enterprise surveys and consider the robustness of the results. To conclude they put forward some ideas to advance research on business climate and growth, and they suggest possible improvements in survey design. JEL codes: L51, O47, O12

In recent years, an unprecedented data collection effort has yielded a set of comparable enterprise surveys covering more than 100,000 firms from 123 countries. As a result, a number of studies have started to analyze the impact of the business climate variables contained in these surveys on different dimensions of firm performance. The general aim of this literature is to generate policy prescriptions based on the identification of the main constraints facing firms. Although many of these studies identify relevant constraints, contradictory or fragile results are also found, pointing to some weaknesses in the methodology 
applied in some papers as well as in the original survey questionnaire design itself.

We review the literature, highlight its main strengths and shortcomings, and propose potential improvements. We begin by stating our motivation for this review, explaining why firm-level analysis - as opposed to a more macroaggregate analysis - of the relationship between enterprise performance and business climate is important for gaining insights. We then review the empirical microeconometric literature using business climate survey data, and consider the robustness of the findings. Finally we put forward some ideas for advancing research on the business climate and suggest possible improvements in survey design. Appendix A presents a comparative view of the key studies analyzing the relationship between enterprise performance and business climate, focusing on datasets, methodology, main variables, and results obtained.

\section{Economic Growth and the Business Climate}

Many structural, institutional, and behavioral variables shape and drive economic growth. The critical variables that collectively define the business climate (also called investment climate) are infrastructure, access to finance, security (meaning the absence of corruption and crime), and the regulatory framework, including competition policies and the protection of property rights. The main hypothesis here is that the business climate affects economic activity throughout the economy and particularly through its influence on incentives to invest. An improvement in the business climate increases returns to current lines of activity and so increases investment in these. It also creates new opportunities-for example through trade or access to new technology. It influences the psychology of entrepreneurs-the Keynesian "animal spirits"-affecting their assessment of whether innovation will pay off. It puts competitive pressure on firms that have enjoyed privileged positions as a result of import or other protection, or special access to government officials. As a result of greater competition, it may cause some firms, perhaps those closer to technological frontiers, to succeed - even as others fail.

Given the complexity of effects that changes in the business climate elicit, different firms, industries, and regions will be affected in different ways. Moreover growth fueled by the business climate is not simply a shift toward some technological frontier. Developing countries must overcome or reduce all kinds of obstacles to efficiency, dynamic and otherwise, without any illusions that the economy will soon reach the frontier. Indeed changes in the business climate may have their most crucial impact far from the technological frontier.

A weak business climate, on the other hand, may not only discourage investment, it can also lead businesses to take costly or counterproductive steps to 
defend themselves from the consequences of its weaknesses. If social order and control are weak, firms typically have to invest heavily in defensive measures such as private security. If the power supply is unreliable, firms will invest in backup electricity generation capacity. If it is difficult to get goods through or to ports, trade is discouraged and larger, more costly inventories are held. Many such constraints on development are not quickly or easily reversed.

On the contrary, improvements in the business climate could generate extra growth dividends through political economy mechanisms if they increase the number of people and enterprises with a stake in a better climate. For example, if trade reforms create an export-oriented sector, that may increase pressure for further reforms to trade policy or trade-related infrastructure. And higher incomes might lead to pressure for an improved business climate in other ways, as people seek rules governing the protection of wealth or capital.

There exists a rich macroeconometric literature which uses cross-country data to relate broad indicators of institutional quality, policy, and infrastructure to a number of macroeconomic outcome variables. ${ }^{1}$ This has yielded interesting insights - broadly speaking, that the business climate significantly affects economic performance- but it is characterized by a number of inherent limitations.

On infrastructure, the seminal paper is Aschauer (1989), which finds that infrastructure capital has a large impact on aggregate total factor productivity (TFP). Many papers (reviewed in Straub 2008, 2010) since then have sought to compare the elasticities of infrastructure capital and private capital. A number of papers estimate a long-run aggregate production function relating GDP to physical capital, infrastructure (transport, power, and telecoms), and human capital. A recent example —Calderón, Moral-Benito, and Servén (2010)—uses a dataset of infrastructure stocks covering 88 countries and spanning the years 1960-2000 and finds statistically (and economically) significant estimates of the output contribution of infrastructure. They imply, for instance, that an increase in infrastructure provision from the median lower-middle income country level (say, Bolivia in 2000) to that of the median upper-middle income country (say, Uruguay) would yield an increase in output per worker of almost 5 percent. An increase in infrastructure provision from median upper-middle income country level to median high-income country level (say, Ireland) would raise output per worker by more than 8 percent.

Regarding institutions and the policy environment, Pande and Udry (2005), as well as Dollar, Hallward-Driemeier, and Mengistae (2005), find compelling evidence that long-run growth is faster in countries that have higher quality legal institutions, better law enforcement, increased protection of private property rights, improved central government bureaucracy, smoother operating formal sector financial markets, increased levels of democracy, and higher levels of trust. World Bank (2004) finds that one of the useful insights of these macroanalyses 
is that secure property rights and good governance are central to economic growth.

The findings of the macroeconometric literature are qualified by concerns about the robustness of the results. The possible endogeneity of infrastructure has been advanced as a reason for contradictory findings on the impact of public capital on long-run economic development. Endogeneity in this context might come from three sources: (a) measurement errors stemming from the use of public capital figures as proxies for infrastructure (see the discussion in Straub 2010); (b) omitted variables, which may arise when there is a third unobserved variable that affects the infrastructure and growth measure; and (c) the fact that infrastructure and productivity or output might be simultaneously determined, that is infrastructure provision itself positively responds to productivity gains.

The precise channels through which business climate variables affect economic growth are still not well understood, and recent studies have been more cautious in their interpretation of the evidence. Durlauf, Kourtellos, and Tan (2008) find some evidence that institutions play a role as determinants of GDP growth rates but they question the robustness of these results and state that the effect is likely to flow through the influence of institutions on physical capital accumulation rates and not via TFP growth directly. Straub, Vellutini, and Warlters (2008) find some evidence of a positive effect of infrastructure on growth, especially in poorer countries, but conclude that in general the results from studies using aggregate data lack robustness. Recent infrastructure elasticity estimates are much lower than earlier calculations which were often fraught with econometric problems such as not accounting for endogeneity or inefficient proxy variables (Romp and de Haan 2005). Other econometric problems, such as the failure to account for model uncertainty in cross-section studies, persist.

The macroeconometric approach has a number of inherent limitations:

- Results display considerable heterogeneity across economies. The explanatory variables at the country level obscure important dimensions of heterogeneity such as variations across different regions within a country, across different types of firms (by firm size, age, ownership type, etc.), or both.

- The limited number of countries restricts the sample size of country-level analyses, especially cross-sectional ones, and thus the robustness of the results.

- Aggregate business climate indicators are often imprecise, rely on de jure information, or subjective judgments about the relative weight of variable components, and lack direct input about actual conditions as experienced by affected parties such as firms.

- Most country-level indicators are invariant over time and thus are indistinguishable from fixed (country, sector, or region specific) effects that may reflect features other than the business climate (Commander and Svejnar 2007). 
- The instruments most often used consist of geographical or historical preconditions (latitude, colonial history, settler mortality, etc.), which limits the ability of the empirical models to identify the consequences of institutional change for growth.

These comments suggest that econometric analysis at a more disaggregated level (firm or industry level) is required to achieve more robust results and leads to more precise policy recommendations - a point that is repeatedly emphasized in World Bank (2004), Pande and Udry (2005), and Durlauf, Kourtellos, and Tan (2008). Such a model should account for the behavior of individual firms in a world where either markets or governments fail, or people face psychological difficulties in taking advantage of opportunities, as suggested by Banerjee and Duflo (2005). To the extent that changes in the business climate affect different firms differently, an aggregate model of business climate and economic growth, with its reliance on a representative firm, is therefore inadequate. Indeed the heterogeneity of firms' responses to changes in the business climate is likely to generate changes in their geographical, industrial, and size distributions.

Relatively simple disaggregated models, addressing the constraints of interest and taking enterprises characteristics (size, ownership, location, type of activities, etc.) into account, can provide a variety of insights; and empirical studies that exploit enterprise surveys are examples of the added value provided by a more disaggregated, microeconomic approach. Note that in the standard theory of profit-maximizing firms, prices of inputs are set equal to their marginal products, so all inputs should be equally "constraining." The discussion of firm-level constraints (high prices of given inputs) would then involve deciding whether these are just intrinsic characteristic of the natural environment (for example the climate) or whether they derive from government failures. However, in practice some key inputs are often not priced at their marginal costs. For example, despite the increasing market mediation of infrastructure, there is also strong evidence that firms' costs and prices are largely not reflecting the "fundamentals" of these activities, so it is implausible that this type of capital is remunerated according to its marginal productivity. ${ }^{2}$ In practice, this makes disentangling the sources of these constraints more difficult.

\section{Recent Enterprise-level Business Climate Studies}

Firm-level business climate data have proved to be a rich source of information on the characteristics of firms and the constraints they face in the developing and transitioning world. This section first describes the characteristics of these surveys and their evolution over time, then reviews the findings of the empirical literature that exploits these surveys to explain firm performance as a function of different aspects of the business climate. 


\section{Datasets}

This section provides an overview of enterprise survey datasets, then examines the structure and content of the standardized core survey instrument. In the paper's conclusions, we make some suggestions to improve the design of the questionnaire.

Overview of Existing Datasets. The crucial prerequisite for finding more disaggregated evidence is the availability of raw disaggregated data. Before the 1990s, standardized firm-level business surveys spanning multiple countries were practically nonexistent. This began to change with an initial series of largely selfcontained projects which carried out business surveys for certain sets of countries and with various thematic scopes.

Four key projects of that period were sponsored by the World Bank: A first set of surveys carried out from 1992 to 1995 by the Africa Regional Program on Enterprise Development; the first round of the Business Environment and Enterprise Performance Survey (BEEPS) for 22 transition countries in 1999; the World Business Environment Surveys (WBES) implemented for 80 countries and the West Bank or Gaza territories from late 1998 to early 2000; and a number of Firm Analysis and Competitiveness Surveys by the Development Economics Research Group. While these projects yielded unprecedented and highly useful data for the countries and issues they were designed for, they suffered from limited comparability amongst each other due to differing questionnaire designs and priorities.

The key development of the early 2000s was a push for greater standardization in order to build up a single, centralized database of comparable business climate surveys from around the world. A set of core questions was "pooled and consolidated" from earlier surveys. This became the crucial component of the new, standardized business climate questionnaires known as Productivity and Business Climate Surveys (PICS). In a specific country survey, around 50-60 percent would consist of the core modules (some 80 questions), the rest would consist of nationally specific ones that could be added flexibly to the core instrument depending on each country's data needs. The core instrument was also partly incorporated into the latest rounds of surveys that had started earlier, for instance BEEPS, the second and third round of which contain most of the core PICS questions. Launched in 2001, the new surveys have been used to acquire detailed firm-level data in 15 to 20 countries a year. The results have been collected in a central database (www.enterprisesurveys.org) along with those of earlier, comparable projects such as BEEPS II and III. All surveys in this database are now commonly referred to as Enterprise Surveys, ${ }^{3}$ although the old terminology (PICS, BEEPS, etc.) persists to some extent. By 2010, the database-which is accessible to anyone who registers - contains information on more than 100,000 firms in 123 countries. Aterido and Hallward-Driemeier (2007, p. 20) outline the key features of this database: "The median sample size is 350 firms, with several large countries having substantially larger samples... The sample of firms in each 
country is stratified by size, sector and location. The unit of analysis is the 'establishment' in the manufacture and service sectors. Most firms are registered with local authorities, although they may be only in partial compliance with labor and tax authorities."

The core questions are generally answered by the manager or owner of the establishment in face-to-face interviews. Accounting data may be provided by the establishment's accountant, human resource manager, or both. Some countries have attached nationally specific modules answered by workers (for instance the Thailand 2007 survey-see World Bank 2008b). Among the earlier surveys, there is still some variation of the core questions, so that comparative analyses of multiple business climate variables may require a focus on a subset of the total database. But there is a large subset of firms and countries for which the data are comparable. Unfortunately important questions (about cost of electricity, number of power outages, or ownership of backup generators by enterprises, for instance) were dropped from most questionnaires after 2006, so that it is not always possible to compare all variables before and after that year.

Structure and Content of the Core Business Climate Survey Instrument. The standardized core survey instrument is organized into two distinct parts. The first part provides general information about the firm and the business climate it faces. The second part collects accounting information such as production costs, investment flows, balance sheet information, and workforce statistics. The questions about the firm and the business climate in the first part include:

- General characteristics of the firm: age, ownership, activities, location

- Sales and supplies: imports and exports, supply and demand conditions, competition

- Business climate constraints: evaluation of general obstacles

- Infrastructure and services: power, water, transport, computers, business services

- Finance: sources of finance, terms of finance, financial services, auditing, land ownership

- Labor relations: worker skills, status and training; skill availability; overemployment; unionization and strikes

- Business-government relations: quality of public services, consistency of policy and administration, customs processing, regulatory compliance costs (management time, delays, bribes), informality, capture

- Conflict resolution or legal environment: confidence in legal system, resolution of credit disputes

- Crime: security costs, cost of crimes, use and performance of police services

- Capacity, innovation, learning: utilization, new products, planning horizon, sources of technology, worker and management education and experience. 
Both subjective data on perceptions of managers and objective data on various business climate indicators are recorded. Tables 1 and 2 are based on surveys covering 41,207 firms in 91 countries during the 2006-09 period. The first table ranks the perceptions of managers about issues that represent constraints for the operation of their enterprise, by geographic region. The severity of the constraints is also a function of the industrial branch they belong to, as shown in table 2 .

There have been considerable discussions about the possible weaknesses of subjective, perception-based indicators compared to objective, quantitative data. Concerns have been raised whether subjective data may be vulnerable to waves of pessimism and euphoria, to inconsistencies across regions and countries because firms compare themselves to different benchmarks (so-called anchoring effects-Bertrand and Mullainathan 2001), or to managers' inability to form accurate subjective estimates (Gelb and others 2007). For instance, managers may fail to separate internal weaknesses of the firm (for example inability to provide proper documentation) from external business climate constraints (for example inefficient bureaucracy). These problems are a specific concern when conducting econometric estimations based on cross-sectional data, and addressing them may require the use of panel data to control for individual or firm fixed effects.

Exploring such concerns, Gelb and others (2007, p. 30) examine subjective data yielded by the core Enterprise Survey perception questions. They conclude that while perceptions of critical business climate constraints may not always correspond fully to 'objective' reality, firms "do not complain indiscriminately," and response "patterns correlate reasonably well with several other country-level indicators related to the business climate." Aterido and Hallward-Driemeier (2007) underline that subjective rankings are highly correlated with objective measures in 16 of the 17 variables and also significantly correlated with external sources, including "Doing Business" indicators. Pierre and Scarpetta (2004), using data from 38 countries, confirm that countries with more restrictive labor regulations are associated with higher shares of firms reporting labor regulations as constraining.

Even if objective and subjective measures are significantly correlated, the latter remain prone to bias. For example, Olken (2009) compares corruption perceptions among villagers in Indonesia with objective measures of corruption in road construction projects. It shows that although these are positively correlated, there are also systematic individual-level biases in the latter. Similar issues are likely to arise in firm-level surveys.

In spite of these problems, subjective indicators can still play a useful role in identifying important constraints through descriptive statistics. Carlin, Schaffer, and Seabright (2006) have highlighted the ease with which a subjective ranking of constraints allows a comparison of the importance of different constraints, as in figure 1 . This is not readily possible with objective indicators that measure 
Table 1. Most Severe Constraint Perceived by Entrepreneurs, by Region (percentage of firms)

\begin{tabular}{|c|c|c|c|c|c|c|c|c|c|c|c|c|c|c|}
\hline Region & $\begin{array}{l}\text { Access } \\
\text { to } \\
\text { finance }\end{array}$ & $\begin{array}{l}\text { Access } \\
\text { to land }\end{array}$ & Corruption & $\begin{array}{c}\text { Court } \\
\text { system }\end{array}$ & $\begin{array}{l}\text { Crime, } \\
\text { theft, } \\
\text { and } \\
\text { disorder }\end{array}$ & Electricity & $\begin{array}{c}\text { Inadequately } \\
\text { educated } \\
\text { workforce }\end{array}$ & Regulation & $\begin{array}{l}\text { Political/ } \\
\text { macro- } \\
\text { economic } \\
\text { framework }\end{array}$ & $\begin{array}{l}\text { Informal } \\
\text { sector } \\
\text { competitor } \\
\text { practices }\end{array}$ & $\begin{array}{c}\text { Tax } \\
\text { administration }\end{array}$ & $\begin{array}{l}\text { Tax } \\
\text { rates }\end{array}$ & $\begin{array}{l}\text { Telecomm- } \\
\text { unications }\end{array}$ & $\begin{array}{c}\text { Transpor- } \\
\text { tation }\end{array}$ \\
\hline Africa & 15.2 & 4.3 & 5.8 & 0.8 & 7.6 & 17.2 & 4.4 & 7.8 & 7.6 & 9.2 & 3.4 & 9.8 & 1.1 & 5.7 \\
\hline $\begin{array}{l}\text { East Asia and } \\
\text { Pacific }\end{array}$ & 22.8 & 4.6 & 4.1 & 0.3 & 3.2 & 10.2 & 8.0 & 8.9 & 4.7 & 17.3 & 2.3 & 8.5 & 0.0 & 5.1 \\
\hline $\begin{array}{l}\text { Europe and } \\
\text { Central Asia }\end{array}$ & 15.9 & 2.6 & 7.0 & 2.0 & 2.5 & 5.5 & 9.7 & 9.3 & 10.7 & 11.1 & 4.5 & 17.6 & 0.0 & 1.7 \\
\hline $\begin{array}{l}\text { L. America and } \\
\text { Caribbean }\end{array}$ & 8.5 & 1.3 & 7.9 & 1.7 & 7.4 & 6.2 & 6.7 & 11.1 & 18.9 & 13.0 & 4.7 & 10.2 & 0.0 & 2.4 \\
\hline South Asia & 13.4 & 6.3 & 4.8 & 0.2 & 9.6 & 17.8 & 3.6 & 7.2 & 26.4 & 2.9 & 2.1 & 2.8 & 0.0 & 3.0 \\
\hline All & 12.8 & 2.7 & 6.8 & 1.4 & 6.4 & 9.9 & 6.6 & 9.6 & 13.3 & 11.6 & 4.1 & 11.2 & 0.3 & 3.5 \\
\hline
\end{tabular}

Note: Data from 41,207 firms in 91 countries for the years 2006-09.

Source: http://www.enterprisesurveys.org. 
Table 2. Most Severe Constraint Perceived by Entrepreneurs, by industrial sector (percentage of firms)

\begin{tabular}{|c|c|c|c|c|c|c|c|c|c|c|c|c|c|c|}
\hline Sector & $\begin{array}{l}\text { Access } \\
\text { to } \\
\text { finance }\end{array}$ & $\begin{array}{l}\text { Access } \\
\text { to land }\end{array}$ & Corruption & $\begin{array}{l}\text { Court } \\
\text { system }\end{array}$ & $\begin{array}{l}\text { Crime, } \\
\text { theft, } \\
\text { and } \\
\text { disorder }\end{array}$ & Electricity & $\begin{array}{c}\text { Inadequately } \\
\text { educated } \\
\text { workforce }\end{array}$ & Regulation & $\begin{array}{l}\text { Political/ } \\
\text { macro- } \\
\text { economic } \\
\text { framework }\end{array}$ & $\begin{array}{l}\text { Informal } \\
\text { sector } \\
\text { competitor } \\
\text { practices }\end{array}$ & $\begin{array}{c}\text { Tax } \\
\text { administration }\end{array}$ & $\begin{array}{l}\text { Tax } \\
\text { rates }\end{array}$ & $\begin{array}{l}\text { Telecommu- } \\
\text { nications }\end{array}$ & $\begin{array}{c}\text { Transpor- } \\
\text { tation }\end{array}$ \\
\hline Textiles & 14.6 & 1.3 & 5.7 & 1.2 & 5.3 & 6.9 & 7.1 & 11.2 & 13.9 & 15.3 & 3.9 & 11.2 & 0.1 & 2.2 \\
\hline Leather & 14.3 & 9.5 & 4.8 & 0.0 & 0.0 & 14.3 & 23.8 & 14.3 & 0.0 & 4.8 & 4.8 & 4.8 & 0.0 & 4.8 \\
\hline Garments & 14.0 & 2.3 & 5.6 & 1.0 & 6.0 & 9.2 & 7.4 & 9.8 & 13.3 & 14.3 & 4.1 & 10.5 & 0.2 & 2.3 \\
\hline Food & 12.2 & 2.2 & 5.9 & 1.5 & 6.9 & 12.0 & 5.8 & 9.6 & 11.9 & 12.7 & 4.1 & 10.8 & 0.2 & 4.2 \\
\hline $\begin{array}{l}\text { Metals and } \\
\text { machinery }\end{array}$ & 13.6 & 2.7 & 7.7 & 1.7 & 5.4 & 8.6 & 8.9 & 10.0 & 12.8 & 8.6 & 4.4 & 13.0 & 0.0 & 2.6 \\
\hline Electronics & 12.7 & 2.0 & 8.6 & 0.5 & 4.4 & 10.2 & 7.2 & 10.0 & 15.8 & 10.3 & 4.4 & 10.2 & 0.0 & 3.8 \\
\hline $\begin{array}{l}\text { Chemicals and } \\
\text { pharma-ceuticals }\end{array}$ & 10.9 & 1.7 & 8.4 & 1.8 & 4.8 & 6.5 & 5.4 & 13.2 & 17.4 & 12.5 & 4.4 & 9.8 & 0.0 & 3.2 \\
\hline Wood and furniture & 18.1 & 2.9 & 3.1 & 0.5 & 1.8 & 9.3 & 11.5 & 10.4 & 4.8 & 13.0 & 4.6 & 16.3 & 0.0 & 3.7 \\
\hline $\begin{array}{l}\text { Nonmetallic and } \\
\text { plastic materials }\end{array}$ & 16.6 & 3.9 & 6.9 & 0.9 & 4.4 & 10.4 & 5.8 & 8.5 & 13.5 & 11.9 & 3.4 & 9.3 & 0.1 & 4.4 \\
\hline $\begin{array}{l}\text { Auto and auto } \\
\text { components }\end{array}$ & 11.5 & 3.6 & 1.8 & 0.6 & 1.2 & 2.4 & 10.3 & 12.7 & 2.4 & 7.3 & 9.1 & 35.8 & 0.0 & 1.2 \\
\hline $\begin{array}{l}\text { Other } \\
\text { manufacturing }\end{array}$ & 12.9 & 3.0 & 6.9 & 1.3 & 6.0 & 13.9 & 6.1 & 8.1 & 13.1 & 10.2 & 3.3 & 10.2 & 0.6 & 4.3 \\
\hline $\begin{array}{l}\text { Retail and wholesale } \\
\text { trade }\end{array}$ & 12.0 & 3.2 & 7.4 & 1.5 & 8.0 & 8.0 & 5.7 & 9.4 & 12.4 & 11.8 & 4.5 & 12.1 & 0.5 & 3.5 \\
\hline $\begin{array}{l}\text { Hotels and } \\
\text { restaurants }\end{array}$ & 13.9 & 3.8 & 5.8 & 0.9 & 6.5 & 16.3 & 8.1 & 6.3 & 10.2 & 9.1 & 4.4 & 12.3 & 0.0 & 2.5 \\
\hline Other services & 11.6 & 2.6 & 6.3 & 1.2 & 6.3 & 10.1 & 7.3 & 9.6 & 15.1 & 10.4 & 4.4 & 11.5 & 0.6 & 3.1 \\
\hline $\begin{array}{l}\text { Construction, } \\
\text { transportation }\end{array}$ & 13.0 & 3.1 & 8.8 & 1.6 & 6.6 & 6.0 & 7.4 & 9.9 & 14.7 & 10.5 & 4.1 & 10.1 & 0.3 & 3.9 \\
\hline All Sectors & 12.8 & 2.7 & 6.8 & 1.4 & 6.4 & 9.9 & 6.6 & 9.6 & 13.3 & 11.6 & 4.1 & 11.2 & 0.3 & 3.5 \\
\hline
\end{tabular}

Note: Data from 41,207 firms in 91 countries for the years 2006-09.

Source: http://www.enterprisesurveys.org. 
Figure 1. Distribution of Firms according to Generator Ownership, by Region

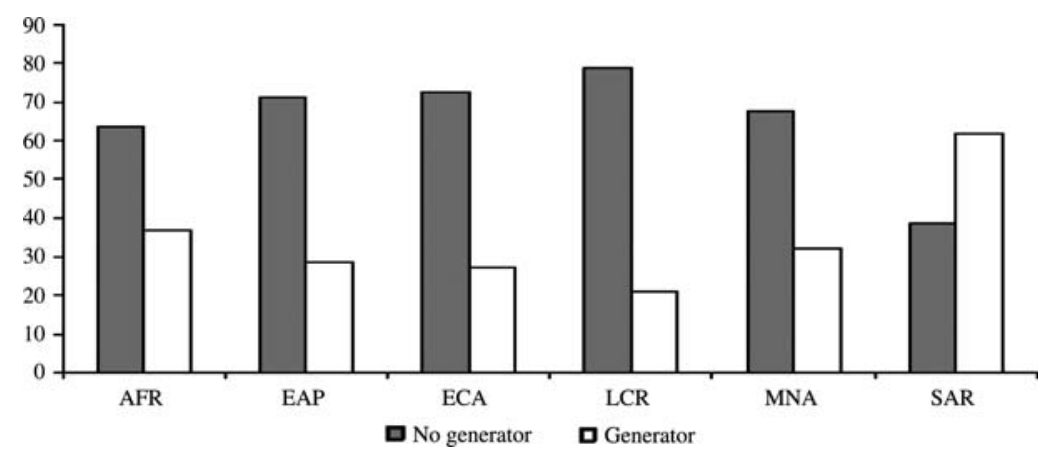

Notes: $\mathrm{AFR}=$ Africa; $\mathrm{EAP}=$ East Asia and Pacific; ECA = Eastern Europe and Central Asia; LCR = Latin America and Caribbean; MNA = Middle East and North Africa; SAR = South Africa region.

Source: Enterprise survey data, 2000-06.

various elements of the business climate in variable-specific units. For instance, it is much easier to ask directly firms to rank the perceived severity of the constraint posed by the power supply relative to corruption, rather than trying to rank it based on two objective measures such as the number of power outages relative to the amount of bribes paid. While over-optimism or pessimism may affect estimates of the absolute level of measured constraint severity, there is no reason to think that average differences between constraint rankings are likely to be biased. Thus subjective data may be helpful in shedding light on the relative importance of different constraints within economies. However, even if they can play an important complementary role, subjective indicators are probably less useful than objective ones in standard econometric analyses.

\section{Recent Findings of the Enterprise-level Literature on Business Climate}

This subsection summarizes the most important results of the recent business climate literature which relates firm performance to business climate indicators. Given that many studies have very specific and limited samples, one must be careful before drawing general conclusions. However, a large variety of samples can be shown to yield essentially similar or complementary results. The subsection is structured by type of constraints, looking in turn at infrastructure (electricity, telecommunications, transport, and water), competition and market regulation, financial constraints, and corruption and crime.

Infrastructure. A pioneering analysis of infrastructure indicators was done by Lee and Anas (1992) and Lee, Anas, and Oh (1996, 1999) for three developing 
countries-Nigeria, Indonesia, and Thailand. Their analyses are not based on the standard enterprise survey data described above but on three dedicated surveys that were carried out in the late 1980s and early 1990s. The infrastructure information they collected, however, is very similar to the one available in the enterprise survey database. ${ }^{4}$ The results presented in these papers are dated by now but the concerns they address remain relevant today. There are large variations in the availability and quality of public infrastructure across countries, regions, and firm sizes. Lee, Anas, and Oh (1999) found that Nigeria tended to have a worse public infrastructure performance and a correspondingly higher incidence of private provision than Thailand and Indonesia, and speculated that the comparatively worse problems of Nigeria are related to the country's then tighter restrictions on private provision arrangements. Aimed at protecting inefficient public suppliers, these restrictions prevented the emergence of private infrastructure provision regimes more efficient than the simple "one firm, one generator" model.

Small firms are disproportionately affected by infrastructure deficiencies. Lee and Anas (1992) find that, in the three countries they study, small firms depend more on public infrastructure and experience more power failures than larger firms because there are economies of scale in private provision of electricity and water: it is relatively cheaper for larger firms to provide their own power and water. This result finds support in Aterido, Hallward-Driemeier, and Pagès (2007) who use more than 80 enterprise surveys to examine deviations from the average ranking of perceived constraints. They find that small firms report electricity as a greater relative constraint than larger firms. ${ }^{5}$ Smaller firms are more likely to be in areas without access to electricity or to be dependent on an unreliable public grid, and lack the scale economies to operate a generator efficiently. Since a large share of new jobs is created by small firms, the negative impact of infrastructure deficiencies on employment creation is potentially huge. Regrettably, none of these papers attempts to measure the potential costs in terms of lost job opportunities of infrastructure constraints faced by small firms.

Infrastructure has a significant impact on enterprise productivity. The most severe constraint is electricity. ${ }^{6}$ Many developing countries are unable to provide their industrial sector with reliable electric power. Many enterprises in these countries have to contend with insufficient, poor-quality electricity and opt for self-generation even though it is widely considered a second-best solution. Table 3 shows the severity of electricity hazards across regions and per capita GDP levels as revealed by enterprise surveys for 104 countries in 2002-06. Survey data on the number of power outages are available for only 87 countries, on backup generators for 77 countries, and on cost of electricity for 34 countries (Alby, Dethier, and Straub 2010). As a result of the constraints faced by enterprises shown in table 1, many firms invest in backup power generators. On average, 31 percent of all firms own a generator (62 percent and 37 percent in South Asia and Africa, 
Table 3. Access to Electricity by Firms across Regions and Country Income Groups

\begin{tabular}{lccc}
\hline Region & $\begin{array}{c}\text { Percent of firms for which electricity } \\
\text { is a major or severe constraint (\%) }\end{array}$ & $\begin{array}{c}\text { Average number of } \\
\text { power outages }\end{array}$ & $\begin{array}{c}\text { Percent of firms having more } \\
\text { than 30 power outages (\%) }\end{array}$ \\
\hline Europe and Central Asia & 8.5 & 9.72 & 5.7 \\
Latin America & 9.3 & 12.44 & 7.7 \\
East Asia and Pacific & 25.1 & 36.49 & 18.3 \\
Mid. East and N. Africa & 21.5 & 41.32 & 22.1 \\
Sub-Saharan Africa & 16.4 & 61.12 & 45.2 \\
South Asia & 43.0 & 131.74 & 49.0 \\
Country group by GDP per capita & & & \\
High & 4.9 & 1.32 & 0.2 \\
Upper-middle & 8.3 & 13.02 & 6.2 \\
Lower-middle & 14.3 & 13.76 & 9.1 \\
Low & 26.4 & 64.08 & 34.1 \\
\hline
\end{tabular}

Source: Alby, Dethier, and Straub (2010) using 2002-06 enterprise survey data.

respectively), with a large variance across firms in terms of number of power outages and generator ownership. These differences correlate significantly with firm size: 46 percent of large firms, 29 percent of medium-sized firms, and 17 percent of small-sized firms report owning a generator. The advantage of this study is that it develops a theoretical model, providing structure to estimate the impact of infrastructure deficiencies on firms' input choices.

Dollar, Hallward-Driemeier, and Mengistae (2005), using survey data from Bangladesh, China, India, and Pakistan, find that, even after controlling for firm characteristics and region- or country-level effects, power losses have a significantly negative effect on total factor productivity. This seems to confirm the importance of electricity in poor countries and more generally the significance of infrastructure for explaining variation in productivity. Aterido and HallwardDriemeier (2007) carry out a related study with particular focus on Africa. They are able to confirm that a higher incidence of power outages has a negative impact on employment growth. African firms seem to have adapted to this problem to some extent so that, for a given frequency of outages, employment growth in Africa is stronger than expected, relative to the rest of the world. This has partly to do with the comparatively high incidence of generator ownership in Africa, which reduces the impact of power shortages from the public grid (Foster and Steinbuks 2009). However, another reason seems to be that a higher frequency of outages seems to have contributed to a disproportional concentration of African employment growth in very small firms, which are less capital intensive and thus less vulnerable to power outages in terms of employment effects. Dollar, Hallward-Driemeier, and Mengistae (2005) draw on a sample of enterprise surveys from Bangladesh, Brazil, China, Honduras, India, Nicaragua, Pakistan, 
and Peru to estimate the probability of exporting of a randomly chosen firm in a given city. They include "losses from power outages" as one business climate indicator and find that it has a negative and significant impact on the probability of exporting.

Infrastructure explains 9 percent of firm-level productivity, which is the second highest percentage after red tape, corruption, and crime in Escribano and Guasch (2005). In this careful econometric study using Guatemala, Honduras, and Nicaragua survey data, various productivity measures are regressed on infrastructure variables (average duration of power outages, number of days to clear customs for imports, shipment losses as fraction of sales, and a dummy for internet access) and controls. For the pooled sample, a 1 percent increase in the average duration of power outages decreases productivity between 0.02 and 0.10 percent, depending on the productivity measure used, and which mainly affects older plants. A 1 percent increase in the fraction of shipment losses will decrease productivity between 1.23 and 2.53 percent, most importantly in old and small firms. Firms with access to the internet are 11 and 15 percent more productive than those firms without access. Some of their results must be interpreted with caution. For instance, the huge impact of internet access on productivity suggests that this dummy functions as a proxy for better equipped, higher-technology firms rather than just representing internet access per se. ${ }^{7}$ This points to a limitation of the econometric methodology to address both production function inputs and the potential endogeneity of investment climate variables. Moreover, firmlevel TFP measured as a residual is a questionable concept in the sense that it may related to both positive and negative aspects, for example monopoly power, in which case results on the relationship between competition and productivity (see below) would be difficult to interpret.

The Escribano and Guasch (2005) methodology has been applied to many country data including Brazil, Chile, Costa Rica, Mexico, Turkey, and Southeast Asia. Escribano, Guasch, and Peña (2010) examine the influence of infrastructure on the average TFP of enterprises in 26 African countries and find that poor-quality electricity provision affects particularly poor countries but can also affect faster growing ones such as Botswana, Namibia, and Swaziland. ${ }^{8}$ Losses from transport interruptions affect mainly slow-growing countries, such as Madagascar or Kenya. Bastos and Nasir (2004) obtain similar results for transition countries (Moldova, Poland, Tajikistan, Uzbekistan, and Kyrgyz Republic). Infrastructure accounts for the second largest share of the variation in firm-level productivity, behind competition but before rent predation. However, their results are not robust because their two-step estimation is vulnerable to simultaneity bias and they do not control for country effects. While they may capture some genuine cross-country differences in all business climate categories, they are also vulnerable to bias if other cross-country effects (such as trade policy or 
political instability) influence productivity and are also correlated with their indicators.

A number of studies linking firm performance and infrastructure suffer from reverse causality. More infrastructure can cause the efficiency of firms to improve, but better economic performance may also attract more infrastructure. Datta (2008) exploits panel data from India to avoid this reverse causality problem. Investigating the effects of a highway improvement program on the productivity of firms, he argues that if "the precise route of the highway was not manipulated to include some intermediate areas (counties, districts, cities) and exclude others based on factors correlated with the outcomes of interest, the highway construction could be treated as exogenous to the areas that the highway runs through." This allows for a difference-in-difference estimation strategy in which changes in relevant outcomes for affected firms are compared to the corresponding outcomes for firms whose location precluded their directly benefiting from the highway program. Since the highway improvement program in question uses the most direct routes between destinations, no opting-out was possible and no realignments was carried out; the areas in between destinations can indeed be viewed as a quasi-random selection of locations with existing highways to which the upgrade treatment was applied. Datta finds that enterprises that profited from the upgrade held significantly lower inventories, became less likely to report transport as a major or severe problem, and showed a greater propensity to change suppliers between the two years (suggesting that they found more suitable ones). He interprets this as evidence that improved highways facilitated productive choices, eased the extent to which infrastructure bottlenecks constrain firms, and allowed them to be more efficient.

Papers that find no significant effects of infrastructure on firm performance are in the minority and generally use specific samples or have methodological limitations. For instance, Commander and Svejnar (2007) use the BEEPS round II and III surveys to regress firm revenue on a number of controls and subjective business climate variables, including a composite infrastructure variable based on the questions from appendix B. They find that perceived infrastructure constraints have a negative and significant effect on firm revenue, but only without controlling for country fixed effects. They conclude quite generally that only country effects (due partly to differences in infrastructure, partly to other unobserved heterogeneities) have an impact, while within-country differences in infrastructure do not. This seems to be a premature conclusion given that significant within-country effects are significant in many other studies and that their sample is limited to Eastern Europe and Central Asia.

Competition and Regulation. The view that competition and entry should promote efficiency and prosperity has now become common wisdom worldwide (Aghion 
and Griffith 2005). Generally speaking, we would expect a positive effect of competition on firm performance and a negative effect of excessive regulation. Studies based on business climate survey data have already confirmed this. They are mainly based on cross-country regressions. Enterprise survey panel datasets which could yield estimates of the impact of regulatory changes over time are lacking.

Using survey data from 60 countries, Carlin, Schaffer, and Seabright (2006) show that anti-competitive practices (as well as tax rates and tax administration, access to and cost of finance, and policy uncertainty and macroeconomic stability) are the most important business constraints in all countries. Gelb and others (2007) look more closely at tax administration and labor regulations and argue that policies become more serious determinants of the business climate at this stage, largely because the state has stronger capacity to implement them. Tax administration is primarily a problem in middle income countries, and the perception of labor regulations as a severe constraint increases with the GDP level of the country. Figure 2, based on 2006-09 enterprise survey data from 91 developing countries, shows the time spent by management dealing with regulators and tax inspectors, by firm size for each major geographical region.

Figure 2. Time spent with regulators, by firm size and geographical region

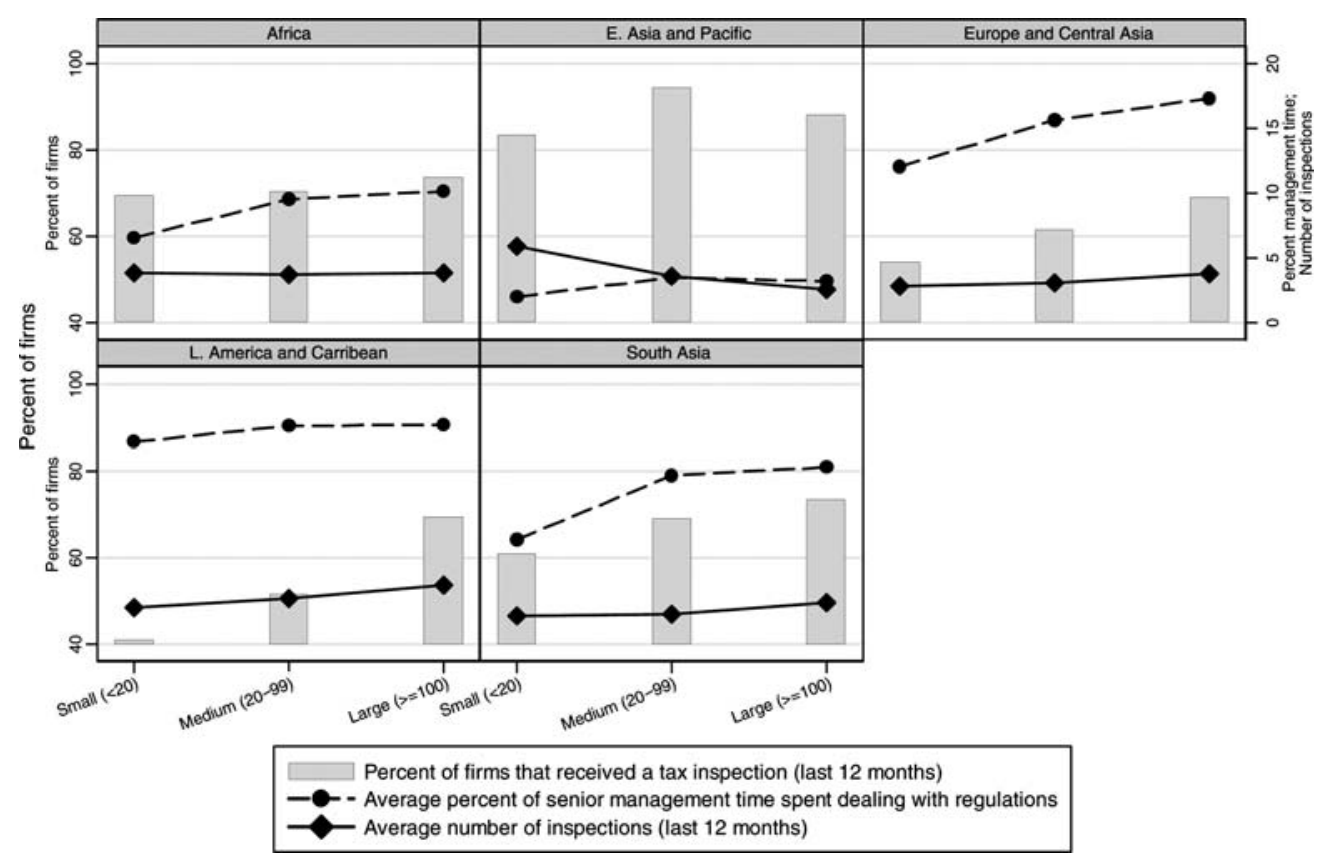

Note: Data from 41,207 films in 91 countries.

Source: World Bank Enterprise Surveys, 2006-09. 
Competition has a significant positive impact on productivity (whether measured as the number of competitors in a main product line or as the importance of domestic or foreign competition to introduce new products or to reduce costs) and explains a far larger part of the variation in enterprise performance than rent predation or infrastructure. Many papers include measures of competition in their business climate regressions, including Bastos and Nasir (2004), Escribano and Guasch (2005), Beck, Demirgüç-Kunt, and Maksimovic (2005), Hallward-Driemeier, Wallsten, and $\mathrm{Xu}$ (2006) and Commander and Svejnar (2007).

Beck, Demirgüç-Kunt, and Maksimovic (2005) find that the "degree of legal obstacles" has a significant negative impact on enterprise productivity but regulation does not necessarily have a negative effect-and has a positive effect when it is consistently enforced. Aterido and Hallward-Driemeier (2007) and Aterido, Hallward-Driemeier, and Pagès (2007) find that consistent enforcement of regulations has a clear positive association with employment growth in most developing countries - though it is not significant for Africa-and is particularly marked for small firms. Both papers also obtain a generally positive effect of management time spent dealing with authorities, which they interpret as representing the benefit from obtaining public goods. On the other hand, pure red tape-for example unnecessary delays in customs - has a significant negative effect. A limitation common to these papers is the potential endogeneity of input choices that may bias the results directly (as for labor in Aterido, Hallward-Driemeier, and Pagés 2007) or indirectly if it affects productivity (as in Escribano and Guasch 2005).

Financial Constraints. The cost of finance and access to finance are often among the most severe constraints faced by enterprises. Across countries, the cost of finance is ranked above average in terms of severity in all country groups by Carlin, Schaffer, and Seabright $(2006)^{9}$ and, on the African continent, it is the highest ranked constraint except in South Africa. ${ }^{10}$ The severity of the access to finance constraint declines with the GDP level of the country in Gelb and others (2007).

Within countries, enterprise size appears to be determinant as it influences the ability of obtaining credit from banks. Beck, Demirgüç-Kunt, and Maksimovic (2005) regress a firm level indicator of financial access ${ }^{11}$ on firm size using 54 datasets from the World Business Environment Survey (http://info.worldbank.org/ governance/wbes/). Even after controlling for a country's institutions, smaller firms report significantly higher financial obstacles than large firms. Ayyagari, Demirgüç-Kunt, and Maksimovic (2008) examine the financing constraints faced by enterprises using the same datasets and conclude that maintaining policy stability, keeping crime under control, and undertaking financial sector reforms to 
relax financial constraints are the most effective ways to promote enterprise growth. Likewise, Aterido, Hallward-Driemeier, and Pagès (2007), on the basis of objective enterprise survey data, find that smaller firms have significantly less access to different forms of finance even when controlling for age, export status, ownership, and industry. The enterprise survey data indicates that small firms tend to finance a much smaller share of their investments with formal credits. Bigsten and Söderbom (2006) show that close to two-thirds of microfirms, but only 10 percent of large firms, are credit constrained in their sample of African countries. In their regressions, controlling for other important factors such as expected profitability and indebtedness, the likelihood of a successful loan application varies with firm size. World Bank (2008a) examines in more details the determinants and implications of lack of access to finance by enterprises. Also, within countries, access to finance is particularly problematic for less productive firms (Carlin, Schaffer, and Seabright 2006).

Financial obstacles have, in the vast majority of studies we reviewed, a negative significant effect on enterprise growth. Beck, Demirgüç-Kunt, and Maksimovic (2005) regress firm sales growth on subjective indicators of financial obstacles ${ }^{12}$ and controls. Six out of the eleven specific financial constraints indicators have a negative and significant impact-but their results could have an omitted variable bias. Moreover they do not calculate location-industry averages and their estimates are vulnerable to reverse causality at the firm level. Aterido, Hallward-Driemeier, and Pagès (2007) are more careful in reducing endogeneity at the firm level. They find that in general a higher share of investments financed externally is associated with greater employment growth. Aterido and Hallward-Driemeier (2007) find that a 10 percent increase in the share of investments financed through bank loans (equivalent to doubling the average share) is associated with a 3 percent increase in employment growth. This result is robust to alternative measures of finance, including formal bank financing of investment to trade credit among firms.

By contrast, Commander and Svejnar (2007) cannot find a significant effect of their subjective 'cost of finance' variable on firm revenue in their dataset from Eastern Europe and Central Asia. ${ }^{13}$ Dollar, Hallward-Driemeier, and Mengistae (2005) find no significant effect of the indicator 'access to overdraft facility' on productivity of firms in the garment industry, but in an expanded sample they do find a significant and strongly positive impact of the variable on annual sales growth. Dollar, Hallward-Driemeier, and Mengistae (2006) find a robust positive relationship between access to overdraft and the probability that a firm is an exporter. The study of the business climate in China by Hallward-Driemeier, Wallsten, and $\mathrm{Xu}$ (2006) yields no significant link between a variety of firm performance indicators and bank access which, as pointed out above, may largely be due to the peculiar nature of the Chinese state-owned banking sector which tends 
to be relatively inefficient and subsidizes unsuccessful enterprises for political reasons.

Corruption and Crime. Crime, bribery, and corruption are identified as major problems for enterprises in less developed countries. Crime and corruption show up as important constraints in all country groups except the OECD, with crime a constraint in 25 percent of countries and corruption in 70 percent (Carlin, Schaffer, and Seabright 2006). Gelb and others (2007) shows that concern about corruption and crime tends to peak in the middle of the per capita income range. They interpret this as meaning that once economies overcome utmost poverty and the most basic limitations related to infrastructure, finance, and macroeconomic stability, problems of low administrative and bureaucratic capacity come to the forefront of firms' concerns.

Recent studies that examine the relationship between firm performance and business climate indicators generally find significant effects for corruption and crime indicators. Fisman and Svensson (2007) use their Ugandan firm-level dataset for a study focused on corruption and its effect on growth. Their OLS and IV regressions of sales growth on a corruption indicator and a variety of controls show a "strong, robust, and negative relationship between bribery rates and the short-run growth rates of Ugandan firms, and ... the effect is much larger than the retarding effect of taxation." Keeping crime under control is one of the most effective ways to promote enterprise growth according to Ayyagari, DemirgüçKunt, and Maksimovic (2008). The enterprise productivity study by Escribano and Guasch (2005) includes "payments to deal with bureaucracy faster as percent of sales" and "number of criminal attempts suffered" as explanatory variables. The coefficient for the number of crimes suffered is significant and negative. However, the size of bribe payments has a robust positive relation with productivity. This may mean that firms that can afford to pay more bribes will tend to be more productive in the first place, reap productivity advantages from their payments, or both. But it certainly does not imply that the incidence of corruption should be seen as positive for productivity in general. Still, the difference in the sign of the corruption variable in the study is somewhat puzzling, and further research would be required to reveal the source of the difference (which could be genuine cross-country variation in the mechanisms of corruption, or related to more problematic endogeneity concerns).

Size of the enterprise matters. Aterido, Hallward-Driemeier, and Pagès (2007) find a significantly negative effect of a bribery dummy and other corruption indicators on the growth of small, medium, and large firms but a significantly positive effect for microfirms. This could mean that microenterprises find it easier to escape the attention of corrupt officials and therefore tend to grow faster than larger firms if the industry-location averages of corruption are higher. In their 
study of the Chinese business climate, Hallward-Driemeier, Wallsten, and $\mathrm{Xu}$ (2006) find that objectively measured corruption matters a great deal for sales growth. ${ }^{14}$ Reducing the mean score of corruption by one standard deviation has a positive effect on sales growth by 6 percentage points. However, no significant effect of corruption can be shown for other firm-performance indicators such as productivity and employment growth. Regressing sales growth on corruption indicators and controls does not yield significance, though the coefficient has the expected negative sign in Beck, Demirgüç-Kunt, and Maksimovic (2005). The authors attribute this to multicolinearity in the sense that the "impact of corruption on firm growth is captured by the financial and legal obstacles." Bastos and Nasir (2004) also find that their rent predation aggregate (which is meant to measure a combination of corruption and regulation) has a significantly negative effect, but it explains less variation of productivity than the infrastructure and competition measures.

\section{Lessons and Ways Forward}

The results of firm-level studies reviewed in the previous section relate enterprise performance to various business climate indicators, along with a series of controls for variables such as firm characteristics, industry, and country effects. These studies provide new evidence about one of the central assertions of the 2005 World Development Report on the business climate, namely that a good business climate drives growth by encouraging investment and higher productivity (World Bank 2004). At least four aspects of the business climate-infrastructure, finance, corruption and crime, and competition and regulation-have been shown to have a significant impact on firm performance.

The firm-level studies have already improved on the macroeconometric literature in a number of respects. They have shown that within-country heterogeneity is important. Variation in local business climate does indeed matter for explaining differences in firm performance. Much the same point is made by single-country, regional-business climate studies such as the China study by Hallward-Driemeier, Wallsten, and $\mathrm{Xu}$ (2006). Moreover the much larger sample sizes made possible by moving to a more disaggregated level allow for more robust results than in aggregate studies. The information obtained from the business climate surveys is also much more detailed and practical than aggregate indicators, allowing, for instance, insights about the variation of business climate effects across regions and different types of firms.

Building on this, it becomes possible to build a rich research program. In this section, we first outline the econometric issues and limitations of the current literature and derive the main lessons. We then highlight what, in our view, are the 
most promising areas for future research. We conclude by opening the debate on potential improvements in the design of existing survey questionnaires.

\section{Econometric Lessons from the Literature}

The standard approach in the literature based on enterprise survey data has been to use regression analysis to identify which - if any - business climate indicators determine firm performance and to what extent. Almost universally, the basic specification of these regressions has been:

$$
\begin{gathered}
\text { Firm Performance } \left.=\beta_{1}+\beta_{2} \text { (Business Climate Indicators }\right)+ \\
\beta_{3}(\text { Firm Characteristics })+\beta_{4}(\text { Additional Controls })+\varepsilon
\end{gathered}
$$

When interpreting results from these regressions, it is important to keep some basic characteristics and limitations of the approach in mind. First, significant coefficients of the explanatory variables are only obtained if there is variation in these variables. The results obtained efficiently pinpoint existing bottlenecks explaining observed variations in firm performance, but they are less useful for identifying universal problems. For instance, Hallward-Driemeier, Wallsten and $\mathrm{Xu}$ (2006) find that access to banking services is not a significant determinant of firm performance in China. However, this does not mean that increasing the availability and efficiency of financial services is unimportant for improving Chinese productivity. As the authors point out, "it only means that the stateowned banking sector has not contributed significantly to regional firm growth." The fact that Chinese state-owned banking has not had a systematic impact on firm performance means that it does not show up as a determinant of actual variation therein. But the common lack of efficient banking services may still be responsible for suboptimal levels of firm performance throughout China. This methodological issue is particularly relevant for studies with small samples because expanding the number of observations will tend to introduce more variation and thus allow more general statements.

A related issue is that of "camels and hippos" raised by Hausmann and Velasco (2005) and discussed in Gelb and others (2007) and other papers. All results are necessarily based on the answers of existing firms that were interviewed. However, if one only interviews those present ("camels in the desert"), one may miss the crucial constraint ("water") of those who have not entered ("no hippos in the desert"). A self-selected sample may imply a lack of variation in the explanatory variables that prevents us from noticing a critical constraint. Gelb and others (2007) argue that such self-selection is hardly ever complete (for example hippos can be expected to live in a water hole at the edge of the desert) and that firms that choose to enter in spite of serious constraints (which may force them into 
costly evasive actions) will perceive them as particularly serious and thus introduce econometrically significant variation. Still, as it stands it is important to recognize that the econometric model above only informs us about the effect of constraints on the sample of existing firms. It is sometimes argued that the more interesting issue is rather the underlying industrial structure (for example the camel/hippo ratio in the desert) which should give away the most important constraint (that is the absence of hippos indicates that the main constraint is the lack of water). This, however, could only be addressed with completely different models such as "entry" models. Also one could think about exploiting a symmetrical issue, namely "exit." Indeed specific type of firms may be more affected by changes in the environment (for example hippos in cases of severe drought). To our knowledge, this has not yet been addressed in the literature, probably partly because consistent panels are just becoming available, partly because of important attrition issues that need to be considered.

Another general methodological problem is that of multicolinearity. If regressors are correlated with each other, estimates will be inefficient and it may be impossible to know the importance of any one particular indicator since it may be serving as a proxy for other, more relevant variables. This is a particular problem with the business climate data, as many indicators are closely related. For instance, the prevalence of email usage may largely move with the quality of electricity supply. This counsels caution when interpreting very specific indicators, and emphasizes the importance of choosing a good regression specification. To some extent, variables such as "prevalence of email" should be seen as proxies for broader infrastructure factors. The solution chosen by Bastos and Nasir (2004) is to aggregate explicitly a number of specific indicators into broader measures (infrastructure, competition, etc.) in order to get clearer results at the loss of some (presumably misleading) detail. However, this makes the derivation of concrete policy implications more difficult.

Endogeneity - that is, a correlation between the explanatory variables and the error term-is more serious than multicolinearity because it causes not only inefficiency and interpretative difficulties, but bias and inconsistency of the estimates. The presence of endogeneity undermines the validity of estimated relationships between business climate indicators and firm performance.

It is unrealistic to assume that firm-level business-climate indicators are exogenous for a number of reasons. First, a major endogeneity problem arises if relevant explanatory variables are mistakenly omitted from the regression equation and also correlated with relevant included regressors. If this is the case, the estimated parameters of the included regressors will pick up some of the impact on the dependent variable of the omitted variables with which they are correlated. This will distort the estimates of the parameters of the included 
regressors, because they will now capture both their own effect and part of that of the correlated omitted variables.

Second, better subjective and objective business climate indicators may be associated with better performing firms, not because they cause such firms to be more productive, but on the contrary because "an inherently more efficient firm can work within the exogenously given environment to reduce inspections, power losses or days for customs clearance or phone lines" (Dollar, Hallward-Driemeier, and Mengistae 2005). Similarly not only may better suited business environments cause firms to be more efficient, but inherently more efficient firms may also be more likely to have the necessary resources to identify and (re)locate to better suited environments. At the aggregate level, inherently more prosperous regions may have greater political clout to obtain infrastructure and other business climate improvements from government. If one cannot fully control for these reverse causality factors, estimates of the effect of the business climate on firm performance will be biased.

The firm-level business-climate literature suggests various measures to limit the endogeneity bias:

- Regressions on single business climate indicators are likely to produce biased and inconsistent parameter estimates due to omitted variables. A sufficiently broad array of indicators and controls should therefore be used in regression equations. The selection of regressors should go from general to specific (Carlin, Schaffer, and Seabright 2006).

- Objective indicators are generally preferable to subjective ones as explanatory variables because they are less vulnerable to measurement error and reverse causality (Bertrand and Mullainathan 2001).

- Using location-industry or industry averages instead of (or as instruments for) the firm-level objective indicators can help alleviate endogeneity due to reverse causality. See for instance Escribano and Guasch (2005); Hallward-Driemeier, Wallsten, and Xu (2006); Dollar, Hallward-Driemeier, and Mengistae (2006); Commander and Svejnar (2007). All use location-industry averages that exclude the respective firm. The idea is that while better region-industry business-climate indicators should explain variation in firm performance, individual firm performance has virtually no impact on the average-indicator. This alleviates direct reverse causality.

- Country-level effects should be controlled for-either with country dummies or with specific country-effects variables - to avoid a contamination of the business climate coefficients with correlated but unobserved country-level effects on firm performance.

- In the absence of panel data, an approach similar to Miguel, Gertler, and Levine (2005) might be useful to alleviate some endogeneity problems. They 
try to explain industrialization-measured as growth in manufacturing employment-at the district level in Indonesia over a 10-year period with social capital indicators at the beginning of the period, but find no effect. A similar approach could be taken with indicators from enterprise surveys.

- A simple two-step estimation procedure estimating TFP as the residual of a production function, then attempting to explain TFP with business climate indicators, is potentially vulnerable to simultaneity bias. The problem is that, in most cases, the production function inputs will be correlated with the indicators because the business climate influences not only productivity per se, but also input choices of firms. This means that in the production function regression, the error term (that is TFP) is likely to be correlated with the regressors (labor and capital) via the business climate, leading to bias. This approach should thus be avoided. Escribano and Guasch (2005) have suggested alternative procedures.

- Considering moreover that TFP, initially defined as a "measure of our ignorance" in aggregated data, is a problematic concept when applied at the firm level, it might be safer though to concentrate on simpler outcomes (for example employment or sales in levels or growth rates) and even to start by deriving firms' input choices from underlying structural models (see Alby, Dethier, and Straub, 2010).

On this last point, a related issue arises with the quality and relevance of the performance proxies used as dependent variables (productivity, profit, sales growth, etc.). Going into the details of the literature on this topic would take us beyond the scope of this paper, but we should note that measures of firm-level productivity are much more likely to run into problems and generate biases since the very construction process of these variables make them likely to be correlated with policy shocks and managerial decisions (see Katayama, Lu, and Tybout 2009). This is not to say that alternative proxies (for example profit, sales, or employment growth) are completely free of problems (see Del Mel, McKenzie, and Woodruff 2007) but again, in many cases, they appear to be preferable.

\section{A Possible Research Agenda}

There remain a number of areas in which additional research could bring interesting results. At the theoretical level, we need to develop a better understanding of the link between firm choices and the business climate in developing countries. A growing body of empirical research is relating cross-country differences in economic outcomes, such as productivity or output per capita, to differences in policies and institutions that shape the business environment. Some empirical research 
has also shed light on the determinants of productivity at the firm level and the evolution of the distribution of productivity across firms within each industrymodeling decisions about investment, R\&D, employment, and so on, which hinge on the type of constraints revealed by the existing surveys (things like credit constraints, infrastructure bottlenecks, level of competition in goods and labor markets, volatility of macroeconomic conditions, entry costs, commitment and enforcement problems or information issues).

Resource misallocation can lower aggregate TFP. Hsieh and Klenow (2009) and Bartelsman, Haltiwanger, and Scarpetta (2009) investigate the effect of firm-level policy distortions on aggregate outcomes. Hsieh and Klenow use microdata on manufacturing establishments to quantify the potential extent of misallocation in China and India versus the United States. They measure sizable gaps in marginal products of labor and capital across plants within narrowly defined industries in China and India compared with the United States. When capital and labor are hypothetically reallocated to equalize marginal products to the extent observed in the United States, they calculate manufacturing TFP gains of 30-50 percent in China and 40-60 percent in India. Bartelsman, Haltiwanger, and Scarpetta (2009) use harmonized data from 24 OECD and Eastern European EU member countries on firm-level variation within industries. They find substantial variation in the within-industry covariance between size and productivity across countries, but this covariance varies significantly across countries and is affected by the presence of idiosyncratic (that is firm-level) distortions.

For developing countries, the literature on firm choices of formality found for example in Rauch (1991), Straub (2005), or De Paula and Sheinkman (2008) can be useful in this context. Together with tools from industrial organization and contract theory, this approach provides a good basis for formalizing insights on market behavior in developing countries. Additionally, results could then be used to understand the very different shapes of firms' distributions we see across countries, for example in terms of size, productivity, or exporting behavior, and guide the empirical applications.

At the empirical level, some of the most interesting insights in the firm-level literature on developing countries have come from studies examining the interactions of business climate indicators with firm characteristics or with each other. For instance, Aterido and Hallward-Driemeier (2007) interact business climate measures with firm sizes to obtain more detailed results on the impact of the business environment on the performance of different types of firms. Honorati and Mengistae (2007), examining the interplay of regulation, infrastructure, financial constraints, and corruption, obtain interesting results, for instance that all three aspects have significant influence on Indian industrial growth, yet their effect depends on the incidence of corruption. Most existing firm-level studies 
have not considered these types of interactions, and more work in this direction could deliver interesting findings laying the groundwork for more precisely targeted policy recommendations.

A key research goal highlighted by a number of authors is that when more survey rounds become available, proper panel data regressions could test for the impact of changes in the business climate on productivity, factor returns, and growth. For instance, whereas current microeconomic studies predominantly aim to assess the variation in firm performance due to local and cross-country variations in existing constraints, panel data could allow an assessment of the impact of changes (reforms) in the shape of different constraints on firm performance, as well as on the entry and exit patterns of firms. However, with only three survey rounds available at most, it is still relatively early for these types of studies.

Even the standard methodological approaches have not yet made full use of the large enterprise survey database. For instance, no best-practice study (properly accounting for endogeneity) of the relationship between firm productivity and the business climate has been carried out for the full, up-to-date enterprise survey database. This has only been done with employment growth as dependent variable (Aterido, Hallward-Driemeier, and Pagés 2007). A very comprehensive study of infrastructure in Africa has finally been published (Africa Infrastructure Country Diagnostic, forthcoming) but not enough analysis is available on the impact of infrastructure on manufacturing firm productivity on this continent (Bigsten and Söderbom 2006). On the other hand, there is also scope to carry out detailed country studies such as that of China by Hallward-Driemeier, Wallsten, and $\mathrm{Xu}$ (2006) or those of India by Honorati and Mengistae (2007) and Amin (2007). It is generally easier to interpret correctly econometric results in singlecountry studies because outcomes are easier to connect to real-life circumstances and complementary data.

Durlauf, Kourtellos, and Tan (2008) argued that the effect of institutions is likely to be through their influence on proximate growth determinants (factor accumulation, in this case) rather than through their effects on technological innovation. It would be interesting to explore this question further with enterprise data. So far, only a few papers have used measures of capital (or human capital) accumulation as a dependent variable and there has been no systematic comparison to the results for TFP.

Future studies should make sure to test extensively the robustness of their results and if possible improve on the methodology in a more fundamental way. This is because even best-practice precautions against endogeneity-such as using location-industry averages as instruments for firm-level indicators, regressing on multiple business climate indicators at a time, and controlling for the current country, region, and industry effects-leave regressions vulnerable to inconsistency and bias, as several researchers have pointed out. For instance, 
location-industry averages are used as instruments to alleviate endogeneity stemming from reverse causality. Yet such endogeneity effects can persist at a more aggregate level as well because of endogenous placement decisions of firms and policy endogeneity. For instance, industry-location averages may yield a strong relationship between firm performance and average quality of telecom services in a specific industry and region. But as Carlin, Schaffer, and Seabright (2006) point out, regions that are prosperous for a variety of other reasons for which it is not realistically possible to control econometrically also happen to have higher levels of telecom services. To counter this effect, some studies (for example HallwardDriemeier, Wallsten, and $\mathrm{Xu}$ 2006) include additional city information and sector dummies to help control for those more macroissues that affect both the business climate and the firm. But the inability to control sufficiently for all factors implies that the endogeneity problem is likely to persist to some extent. In light of this, it is clear that the need arises both for more modeling efforts (for example Alby, Dethier, and Straub 2010) and for more creative instrumental strategies. Some examples of the latter can be found in the literature-for example in Duflo and Pande (2007), who use geographical data to instrument for the endogenous placement of infrastructure, or Datta (2008) and Gibson and Rozelle (2003), who take advantage of the seemingly exogenous placement of road works in specific contexts to assess their impact.

One final comment on translating the findings of this literature into policy. Regression results based on data provided by firm managers are often straightforwardly translated into policy advice, for example to increase competition and lower regulation. The underlying assumption is that changes in the business climate which improve firm performance will translate into broad social benefits. Yet this may not always be the case. In order to reduce the risk of any negative impact on social welfare, it is wise to consider possible competing interests when examining policy implications. For instance, regulations may impact on firm productivity negatively but provide benefits to nonmanagerial social groups.

\section{Improving Questionnaire Design}

At a fundamental level, it may also be worthwhile to rethink the standard enterprise survey questionnaire which determines the raw data on which all analyses are based. For instance, in the era of cellphones-which are particularly important in many developing countries - the focus on mainline telephone services is anachronistic and misleading. With regard to infrastructure indicators, Straub (2008) makes a number of suggestions for more detailed questions such as firms' access to alternative transport modes (railways, airports, roads, etc.) or the ownership of vehicles. 
There appear to be many holes in the information provided. In electricity, for example, most information is on quality (outages and cost thereof) but basic information on cost and availability of service, such as average cost of a kilowatthour of electricity from the public grid or cost of power generators, is absent. Similarly, for water, information is sought on the sources of provision but it should be complemented with the respective average unit costs. In transport, data on the possibility to access different types of services (roads, railways, etc.) together with an assessment of their unit cost and quality, and the ownership of different types of vehicles, would make it possible to assess the significance of the transport mix chosen by firms. In the case of telecommunications, mobile telephony is completely absent from existing surveys. Here again, data on access, unit cost, type (such as gathering information on markets, money services, etc.), and quality of services derived from mobile phones would be necessary. One also wonders why questions geared at the use of the internet are restricted to the subsample of service firms.

Finally a few key dimensions would need to be added. First, information on the institutional nature of service providers and regulatory arrangements would be crucial from a policy perspective. Moreover in a context where the geographical dimension is increasingly recognized to be important (Gibson and McKenzie 2007; Straub 2008), data need to be spatially referenced. Obviously the practical task of gathering this type of data (including in particular several hours spent with directors and managers of firms, who often have imperfect knowledge about the things they are asked to report) implies a trade-off between being exhaustive and collecting data of good quality. 
Appendix A: Studies of the Relationship between Enterprise Performance and Business Climate

\begin{tabular}{|c|c|c|c|c|}
\hline Paper/Dataset & Type of analysis & Dependent variables & Independent variables & Results/critique \\
\hline $\begin{array}{l}\text { Bastos and Nasir (2004) } \\
\text { "Productivity and Business } \\
\text { Climate: What matters } \\
\text { most?" } \\
\text { Using BEEPS II extended } \\
\text { dataset for Kyrgyz } \\
\text { Republic, Moldova, Poland, } \\
\text { Tajikistan \& Uzbekistan }\end{array}$ & $\begin{array}{l}\text { Estimation of TFP and } \\
\text { subsequent regression of } \\
\text { TFP on three measures (rent } \\
\text { predation, infrastructure, } \\
\text { and competition) } \\
\text { constructed from individual } \\
\text { survey indicators using } \\
\text { principal component } \\
\text { analysis. } \\
\text { Determination of the relative } \\
\text { importance of the three } \\
\text { business climate regressors } \\
\text { using Kruskal (1987) } \\
\text { methodology. }\end{array}$ & Ln (TFP) & $\begin{array}{l}\text { Rent predation variable, based } \\
\text { on: } \\
\text { - amount of unofficial } \\
\text { payments to public officials } \\
\text { as percent of sales } \\
\text { - senior management time } \\
\text { spent in dealing with red } \\
\text { tape } \\
\text { - days last year spent on } \\
\text { inspections. } \\
\text { Infrastructure variable, based } \\
\text { on: } \\
\text { - days of interrupted phone } \\
\text { service } \\
\text { - days of interrupted water } \\
\text { service } \\
\text { - days of interrupted power } \\
\text { service. } \\
\text { Competition variable, based } \\
\text { on subjective estimates of } \\
\text { importance of domestic/ } \\
\text { foreign competition to } \\
\text { introduce new products/ } \\
\text { reduce costs. } \\
\text { Control variables: Firm age, } \\
\text { Exports (as percent of sales), } \\
\text { Foreign ownership. }\end{array}$ & $\begin{array}{l}\frac{\text { Results }}{\text { The business climate }} \\
\text { variables have the expected } \\
\text { signs and are jointly } \\
\text { significant. } \\
\text { Using Kruskal methodology, } \\
\text { competition is found to } \\
\text { explain far more variation } \\
\text { in firm-level productivity } \\
\text { than infrastructure, which } \\
\text { in turn explains more } \\
\text { variation than rent } \\
\text { predation. } \\
\text { Critique } \\
\text { Country dummies are not } \\
\text { included (see critique of } \\
\text { Commander and Svejnar } \\
\text { 2007). } \\
\text { Two-step estimation } \\
\text { procedure vulnerable to } \\
\text { simultaneous equation bias } \\
\text { as outlined by Escribano } \\
\text { and Guasch (2005). }\end{array}$ \\
\hline
\end{tabular}


Beck, Demirgüç-Kunt, and

Maksimovic (2005)

"Financial and Legal

Constraints to Growth:

Does Firm Size Matter?"

Using 54 datasets from the

World Business

Environment Surveys (WBES)
To find out whether firm size determines perceptions on financing, legal, and corruption constraints to doing business, the authors carry out OLS regressions of firm-level financing and legal and corruption indicators on firm size, controlling for country level financing, legal, and corruption constraints.

To see whether variations in perceived obstacles can explain firm sales growth, the authors carry out OLS regressions of firm growth on business climate indicators (one at a time), controlling with industry dummies, firm

characteristics, and country random effects.

To explore how the effects of business climate indicators differ by firm size, size
32 subjective business climate variables in financial, legal, and corruption categories.

Firm growth (percent change in firm sales over past three years). objective IC indicators for more specific constraints within the three summary categories.

Controls: Ownership

(government and foreign);

Exporter status; number of competitors; industry

dummies; country dummies (inflation; GDP; GDP per capita; GDP growth). 
controls are added as explanatory variables.

Dollar, Hallward-Driemeier, and Mengistae (2005)

"Business climate and Firm

Performance in Developing

Economies"

Using four World Bank

Enterprise Survey datasets

for Bangladesh, China,

India, and Pakistan
GLS and Levinsohn/Petrin production function estimation of TFP in the garments industries of all countries. TFP is then regressed on the logs of a set of business climate variables and controls.

Regression of factor rewards in garments industries on the same variables plus firm characteristics. The
For pooled data (all

industries):

- Sales growth

- Annual growth rate of fixed assets

- Annual growth rate of employment.

For garments industry only:

- TFP

- average wage

- average profit. obstacles have a much greater impact on the operation and growth of small firms than on that of large firms.

Critique Study uses few objective business climate indicators (3 out of 35).

Results on the 32 specific business climate variables are based on regressions of firm growth on each of the variables in turn, therefore likely omitted variable bias.

Business climate variables:

- $\log$ (custom days export)

- $\log$ (custom days import)

- $\log$ (power loss)

- $\log$ (days to get phone)

- $\log$ (overdraft facility).

Instrumented by city-sector averages.

Control variables (not all in every regression): $\log$ of: distance from market; distance from port;
Results

IC explanatory variables show consistent joint significance, and often individual significance as well, for the level of productivity, wages, profit rates, and the growth rates of output, employment, and capital stock at the firm level—in garments and similar sectors.

Results robust to inclusion 
hypothesis is that factor rewards will be higher when business climate is better.

Regression of sales growth, growth in fixed assets, and growth in employment in all industries (pooled dataset) on business climate variables and controls.

All regressions carried out for the full sample and a

Escribano and Guasch (2005)

"Assessing the Impact of the Business climate on Productivity Using Firm Level Data: Methodology and the Cases of

Guatemala, Honduras and

Nicaragua"

Using ICA datasets for

Guatemala, Honduras, and Nicaragua

Paper objective is to develop a consistent econometric methodology to be used as a benchmark for evaluating the impact of IC variables on productivity at the firm level. The methodology is then applied in the cases of Guatemala, Honduras, and Nicaragua.

The econometric analysis consists of a variety of subsample of small firms.

population; lagged annual sales; lagged age of firm; fixed assets at start of year; last year's employment; also country, year, and industry dummies. regressions of productivity measures on business
Productivity at enterprise Business climate variables: level (10 different instrumented by regionmeasures)

industry averages.

Red tape, corruption, and

crime:

- no. of days spent in inspection and regulation related work

- fraction of sales undeclared

to tax authorities

- payments to deal with bureaucracy faster (\% of sales) of country dummies which shows that business climate at local level is important. Critique Regressions with TFP potentially vulnerable to simultaneity bias.

However, results largely confirmed with alternative firm-performance dependent variable. $\underline{\text { Results }}$

Analyses which use twostep procedure (first estimate firm productivity, then regress this measure on IC variables) are likely to suffer from simultaneity bias. Therefore paper proposes three different methods to estimate productivity

Use of four categories of business climate variables deemed important for 


\begin{tabular}{|c|c|c|c|c|}
\hline Paper/Dataset & Type of analysis & Dependent variables & Independent variables & Results/critique \\
\hline & \multirow{2}{*}{\multicolumn{2}{|c|}{$\begin{array}{l}\text { climate indicators and a set } \\
\text { of controls. Results are also } \\
\text { analyzed by country, age, } \\
\text { and size of firms. }\end{array}$}} & $\begin{array}{l}\text { - no. of criminal attempts } \\
\text { suffered infrastructure } \\
\text { - average duration of power } \\
\text { outages (log) } \\
\text { - days to clear customs for } \\
\text { imports (log) } \\
\text { - shipment losses (\% of sales) } \\
\text { - dummy for internet access. } \\
\text { Quality, innovation, and } \\
\text { labor skills: } \\
\text { - fraction of computer } \\
\text { controlled machinery } \\
\text { - fraction of total staff } \\
\text { engaged in R \& D } \\
\text { - dummy for ISO quality } \\
\text { certification } \\
\text { - fraction of total staff with } \\
\text { secondary or higher } \\
\text { education } \\
\text { - dummy for training beyond } \\
\text { "on the job" training. }\end{array}$ & $\begin{array}{l}\text { Guatemala, Honduras, and } \\
\text { Nicaragua: (a) red tape, } \\
\text { corruption, and crime; (b) } \\
\text { infrastructure; (c) quality, } \\
\text { innovation, and labor skills; } \\
\text { and (d) finance and } \\
\text { corporate governance. } \\
\text { Estimates show consistently } \\
\text { high impact of business } \\
\text { climate (especially red tape, } \\
\text { corruption and crime, and } \\
\text { infrastructure) on } \\
\text { productivity. Overall, it } \\
\text { accounts for over } 30 \\
\text { percent of productivity. } \\
\text { Critique It is not clear that } \\
\text { endogeneity of production } \\
\text { function inputs is } \\
\text { adequately solved. Moreover } \\
\text { firm-level TFP is a fuzzy } \\
\text { concept that may cover } \\
\text { many aspects, both positive } \\
\text { and negative. }\end{array}$ \\
\hline & & & $\begin{array}{l}\text { Finance and corporate } \\
\text { governance: }\end{array}$ & \\
\hline
\end{tabular}


- dummy for incorporated company

- dummy for external audit.

Controls: Age of firm (log); share of imported inputs: country; firm size.

Business climate variables:

- reported bribe as share of sales

- reported tax as share of

sales .

Taxation Really Harmful to

Growth? Firm Level

Evidence"

Using Uganda Industrial

Enterprise Survey Dataset a significant impact of

[log(sales1997-

firm sales growth,

controlling for other factors
Regression analysis to test for

Instrumented by location-

industry average.

Index $(0-5)$ of availability of public services (electricity,

water, telephone, waste

disposal, paved roads).

Index of regulation (log of

$1+$ percentage of senior

management time spent

dealing with regulation).

Control variables:

Ownership (foreign $>50 \%$ ):

log of firm age; (log of) sales

in 1995; trade (firm exports

and/or imports).

Results Both taxation and bribes are found to have a robust, significantly negative impact on shortrun sales growth; the retarding effect of bribes is thereby stronger than that of taxes. Foreign ownership has a positive impact on sales growth, as does trade status at least in one specification 


\section{Appendix A. Continued}

Paper/Datase

Dollar, Hallward-Driemeier, and Mengistae (2006)

"Business Climate and International Integration" Using eight World Bank Enterprise Survey datasets for Bangladesh, Brazil, China, Honduras, India, Nicaragua, Pakistan, and Peru

Carlin, Schaffer, and

Seabright (2006)

"Where are the Real

Bottlenecks? A Lagrangian

Approach to Identifying

Constraints on Growth

from Subjective Survey

Data”

Using 60 World Bank
Type of analysis

Probit regression of export status on business climate indicators and control variables (geographic, sector, firm characteristics). The aim is to relate business climate to the probability that a randomly chosen firm in a particular city exports. Country dummies are used in some specifications to obtain analysis of withincountry variation.

Overview of descriptive statistics of subjective business climate indicators.

Development of model of the firm to predict relationship between reported

Dependent variables

Indicator variable of whether firm exports or not

Indicator variable of whether firm has foreign ownership or not

TFP (defined for

manufacturing firms using TFP residuals or the firms' self-reported technological level)
Independent variables

Business climate variables:

Three objective business

climate indicators: days to

clear customs; access to

overdraft; losses from power outages.

One subjective business climate indicator: whether managers thought government services inefficient.

The authors use location averages to instrument the variables.

Control variables: distance to international market; distance to port; population; population squared; country dummies; sector dummies; firm size (employment). Business climate variables:

17 subjective indicators of the severity of different business climate constraints on a four/five point scale (see appendix B in the text). Control variables: Country dummies; ownership
Results/critique

Results Paper finds that a sound business climate-as reflected in low customs clearance time, reliable infrastructure, and good financial services-makes it more likely that domestic firms will export, enabling the more productive firms to expand their scale and scope.

The empirical link is largely robust to the inclusion of country dummies (at least joint significance and some individual significance remains) showing that local factors matter for the business climate.

$\underline{\text { Results }}$

Descriptive statistics show that physical infrastructure rarely rates highly as a constraint; problems with licensing and customs affect relatively few countries (especially CIS); crime and/ or corruption show up as 
Enterprise Survey datasets from BEEPS 2002, 2004 and 2005, and PICS

2000-05. constraints and the

characteristics of firms.

Regression of TFP on business

climate and controls. (foreign/government/new

and private owned); big city. important constraints in all groups of countries except the OECD; seven

dimensions of the business environment that are ranked as of greater than average importance in all country groups: anticompetitive practices, tax rates and tax

administration, access to and cost of finance, and

policy uncertainty and

macroeconomic stability.

Regressions yield results in

line with model predictions.

Between-country

regressions show negative and significant effects of telecom, electricity, transport, customs regulation, Mafia, land title, and land access indicators.

Once country effects are controlled for, however, customs regulations, transport, and legal system indicators have perverse positive signs. Authors 
argue that this is due to endogeneity bias. Finance has significant negative impact, as predicted because it does not have public good characteristics but instead inherently unproductive firms are rationally denied credit (and complain about this). Critique

First, instead of objective indicators, the authors use subjective ones which are particularly vulnerable to the endogeneity effects they allege. Second, regressions only use one business climate indicator at a time, exposing them to omitted variable bias. Third, the posited relationship between firm performance and perceived indicator severity can only be shown for customs regulation and finance but not for any of the other disaggregated indicators. When avoiding 
Hallward-Driemeier,

Wallsten, and Xu (2006)

"Ownership, Business

Climate and Firm

Performance"

Using China PIC Survey

2000 (from World Bank

Enterprise Survey database)
Regression of four different firm performance variables on largely objective business climate indicators (measured as city-industry averages)

and controls
- Sales growth

- investment rate

- productivity

- employment growth
Business climate variables:

- mean loss of sales due to transport/power outages

- mean share of labor that uses computers

- mean share of R\&D staff in labor

- mean regulatory burden

- mean corruption

- mean share of nonpermanent labor

- mean bank access.

Control variables:

Ownership (domestic private/ foreign); logs of firm age +1 and firm age +1 squared; log lagged sales; log lagged these problems, other authors do find

nonperverse, significant effects even when employing country dummies. Fourth, authors do not use industrylocation averages of their regressors, which could

lessen firm-level

endogeneity biases.

$\underline{\text { Results }}$

- ownership significant, foreign ownership more

so than private domestic

- no evidence that physical infrastructure matters significantly, but technological infrastructure does (expected given that road and power are good quality in China)

- labor market flexibility weakly significant

- no evidence that average access to finance in a region and industry affects performance 


\begin{tabular}{llll}
\hline Appendix A. Continued & & & \\
\hline Paper/Dataset & Type of analysis & Dependent variables & Results/critique \\
\hline & & employment; log city & (expected given inefficient \\
& & population and GDP per & Chinese bank sector) \\
& & capita; city and industry government regulatory & burden and corruption \\
& dummies. & strongly significant.
\end{tabular}

As expected, ownership has strong effects on firm performance. Relative to state ownership, domestic private ownership is associated with a higher sales growth rate and investment rate. Effect of foreign ownership even larger. There is no evidence that physical infrastructure affects firm performance but the impact of technological infrastructure appears to matter significantly. Labor market flexibility matters weakly. Critique The two-step TFP regression is vulnerable to simultaneity bias (see Escribano and Guasch 2005). However, the 
Aterido, Hallward-Driemeier,

and Pagés (2007)

"Business Climate and

Employment Growth: The

Impact of Access to

Finance, Corruption and

Regulations Across Firms"

Using Datasets from World

Bank Enterprise Surveys

database
A descriptive overview of

firm-level employment growth and business

climate data from over 100

countries, focusing in

particular on differences

by firm size.

Regression of employment growth on IC constraints controlling for a variety of firm characteristics (especially size) and other factors.

\section{- Firm}

growth.

employmen

Change in the enterprise's permanent employment, divided by the firm simple average of permanent workers during the same period. The measure is symmetric and bounded by $+/-2$.
Business climate variables: Country-city-sector-size averages of the following variables:

Finance:

- firm has overdraft facility

- percent of sales sold on credit

- percent of working capital financed externally

- percent of investments financed externally.

Regulation:

- $\log$ of days to get an operating license in last two years

- percent of management's time dealing with government regulation

- $\log$ of days spent on inspections last year

- log of average days to obtain imports last year authors also use other firm performance measures which produce at least approximately similar results.

$\underline{\text { Results }}$

Significant differences across size categories of firms - both in terms of objective conditions faced by firms and nonlinearities in the impact of these conditions. Low access to finance, corruption, poorly developed business regulations, and infrastructure bottlenecks shift downward the size distribution of employment. Low access to finance and ineffective business

regulations reduce the growth of all firms, especially micro- and small firms. Corruption and poor infrastructure create growth bottlenecks for medium and large firms.

The results also reinforce 
- $\log$ of average days to get exports through customs last year

- $\log$ of total days spent on labor inspections last year.

Corruption:

- firms in comparable activities bribe to get things done (yes/no)

- bribes as percent of sales to get things done by similar firms

- similar firms give gifts to officials (yes/no)

- percent of government contracts on bribes by comparable firms

\section{Infrastructure:}

- power outages during the last year (log days)

- percent of sales lost due to power outages last year

- $\log$ of days with no water last year. the importance of differentiating the impact across size classes of firms that allow for the micro firms (less than 10 employees) to be different from small firms.

A weak business climate reduces overall employment in the business sector. Firms may be confined to industries with limited innovation and growth opportunities. In addition, a larger share of firms may remain informal or semiinformal, reducing the capacity of the state for collecting taxes and paying for fundamental inputs for development such as education. 
Aterido and HallwardDriemeier (2007)

"Impact of Access to Finance, Corruption and Infrastructure on

Employment Growth:

Putting Africa in Context"

Using World Bank

Enterprise Survey database, with a focus on Africa
Descriptive overview of how

African employment

growth rate compares to

the rest of the world, and

how specific business

climate constraints differ

across regions and types of

firms.

Regression of employment growth and other outcome variables on a set of business climate indicators and controls for two country samples (African countries and other

developing countries).
- Employment growth

- capital intensity

- change in capital intensity.
Controls:

Firm size (micro/small

/medium/large); firm age (young/ mature/old);

location (large and small cities); ownership (foreign or government); exporter;

industry; country.

Business climate variables:

- share of investments

financed with bank loans

- days without power

- management time with officials

- frequency of bribes to "get things done."

Alternative specifications include: days to clear import customs; consistency of enforcement of regulations; share of sales on credit.

Control variables (not all in every regression): firm size, firm age, export status.

foreign ownership, sector controls; survey dummies, country controls.

\section{Results}

Firms in Africa face greater obstacles in terms of finance, infrastructure, public services, and governance. The more challenging business environment conditions do not translate into lower average growth compared to other developing countries, but they are associated with shifting down the firm size distribution, lowering the relative growth of larger firms, or in some cases expanding microfirms. This may be because there are incentives to remain small, e.g. because bad 
Commander and Svejnar (2007)

"Do Institutions,

Ownership, Exporting and Competition Explain Firm Performance? Evidence

\section{Countries"}

Using Dataset from BEEPS II and BEEPS III (Crosssectional analysis but authors also construct panel subset with approx. 1,300 firms)
Authors regress log of firm sales revenues on

subjective business climate indicators and a set of controls (OLS and IV).

Using a constructed panel of 1,300 firms, regression of change of revenues between 2002 and 2005 on the 2002-05 rate of change of labor and capital and on the initial 2002 levels of the business environment constraints and structural variables (OLS).
Log of firm sales revenues.

Log of change in firm sales revenues.
Firm level business climate variables from BEEPS

(subjective perceptions of managers on 1-4 scale):

- cost of financing

- tax rates

- custom/foreign trade regulations

- business licensing and permit

- macroeconomic instability

- functioning of the judiciary

- corruption

- street crime theft and disorder

- anti-competitive practices

- infrastructure.

Country-level business climate variables (in separate regressions):

- 12 "doing business" variables contact with corrupt state

$\underline{\text { Results }}$

Country effects matter for firm performance but differences in the business environment constraints observed across firms within countries do not. Foreign ownership found to have positive effect on firm performance, but domestic private ownership not.

Export orientation found to have positive effect only in simple specification, not if authors control for ownership.

Critique

Paper uses only subjective, perception based business climate indicators. Objective business climate indicators, such as the time required to clear customs, have been found to be significant even 
- 10 heritage foundation indices of economic freedom.

Control variables (not all in every regression): levels of capital and labor inputs; categories of ownership (privatized, new private, foreign); export orientation of firm; log of exports/sales.

Note that main controls are replaced by instrumental variables. with the inclusion of country dummies (e.g. by Dollar, Hallward-Driemeier, and Mengistae 2005)

Subjective business climate indicators may be suboptimal because systematic variations in perceptions in the crosscountry dataset are largely a function of broad business confidence related to macrofactors such as political and

macroeconomic stability or the financial system. Such country level effects are largely captured by country dummies. Once firm characteristics (such as size or age) are also controlled for, the remaining variation in perception based indicators of specific business climate constraints may be largely due to random factors such as managers' personality. This could explain why these subjective indicators do not 
show up as significant,

although concrete objective measures of the business

\section{Honorati and Mengistae} (2007)

"Corruption, the Business Environment, and Small Business Growth in India" Using data from Indian Firm Analysis and 2002 and 2005
Descriptive analysis of objective and subjective data.

Regressions analysis to examine the effects of corruption, labor regulation, access to finance, and the quality of power supply on the growth of manufacturing businesses in India.
Annual sales growth

Business climate variables:

- lagged profitability (finance proxy)

- lagged indebtedness (finance proxy)

- indicators of corruption, labor regulation, and power shortages.

Controls:

industry, state, and year dummies; initial size. climate may do.

Results

The authors find a pattern whereby the better performing states are also better in every important aspect of their business environment: low-income, low-growth states have the worst indicators of all institutional variables except for labor regulation. Regressions show that average business growth rate is lower where labor regulation is greater, power shortages are more severe, and financial constraints stronger. Influence of each of these three factors on business growth depends on the incidence of corruption, sales growth is constrained by cash-flow only in businesses that are not affected by labor regulation, 
power shortages, or corruption.

The authors interpret this as indication that

corruption is a proxy for something more

fundamental than the

payments of bribes, namely the quality of property right institutions. Their results are consistent with the view that the quality of property rights institutions exerts more abiding influence on economic outcomes than the quality of contracting institutions. 


\section{Appendix B: Infrastructure Variables - Subjective and Objective Questions}

In the core survey questionnaire, there is one subjective perception variable for three types of infrastructure: electricity, transport, and telecommunications:

- Rate whether the following issues are a problem for the operation and growth of your business on a five point scale from 'No obstacle' up to 'Very severe obstacle':

(a) Telecommunications, (b) Electricity, (c) Transportation.

[14 other non-infrastructure issues are also listed, including customs/trade regulation, labor regulation, etc.]

There are also a number of objective indicators:

- During how many days last year did your establishment experience the following service interruptions, how long did they last, and what percent of your total sales value was lost last year due to: (a) power outages or surges from the public grid? (b) insufficient water supply? (c) unavailable mainline telephone service?

- Does your establishment own or share a generator? If yes, what percentage of your electricity comes from your own or a shared generator?

- What share of your firm's water supply do you get from public sources?

- What percentage of the value of your average cargo consignment is lost while in transit due to breakage, theft, or spoilage?

- Does your enterprise regularly use email or a website in its interactions with clients and suppliers?

- Based on the experience of your establishment over the last two years, what is the actual delay experienced (from the day you applied to the day you received the service or approval) and was a gift or informal payment asked for or expected to obtain for each of the following? (a) A mainline telephone connection, (b) An electrical connection, (c) A water connection, (d) ... [three other non-infrastructure issues].

Some changes to the core instrument have been made over time. For infrastructure, for instance, there were two additional questions which, unfortunately, were omitted after 2006:

- What is your average cost of a kilowatt-hour (kWh) of electricity from the public grid?

- If yes [on generator ownership], what was the generator's original cost to your establishment? 
These questions were omitted even though, in 2006, on average, close to half of all the firms surveyed experienced more than 30 power outages per year and 31 percent of firms owned a backup power generator. Specific national surveys may add infrastructure questions to augment the core survey.

\section{Notes}

J.-J. Dethier (corresponding author) is a research manager and Max Hirn is a junior professional officer, both at the World Bank. Stéphane Straub is professor at the Toulouse School of Economics, Arqade. Their email addresses are jdethier@worldbank.org; mhirn@worldbank.org; and stephane. straub@univ-tlse1.fr. The authors are grateful to Howard Pack, Emmanuel Jimenez, and three anonymous reviewers for helpful comments, and to Rabia Ali for outstanding research assistance.

1. Typically GDP per capita (for example in Acemoglu, Johnson, and Robinson 2001), GDP per worker (for example in Hall and Jones 1999), or their growth rates (for example in Knack and Keefer 1995 or Mauro 1995).

2. As discussed in Pritchett (2000), it is unlikely that infrastructure investment results from the equalizing of costs and benefits, as governments are usually not profit maximizers. The exact mapping between investment and the value of infrastructure created rather involves issues such as lack of efficiency in public investment, corruption, and wasteful public spending.

3. Not to be confused with the World Business Environment Survey (WBES) mentioned above, which was a one-off project in 1999-2000.

4. In both types of surveys, key descriptive statistics are calculated (number of firms that own a generator or a private well; production time, sales value lost due to public infrastructure interruptions etc., or both). Stratification and sample sizes are also similar in both cases (a few hundred enterprises per country and year, stratified by industry, region or city, and firm size).

5. World Bank (2004), in figure 6.4, reports that a greater percentage of large firms rank infrastructure constraints as major or severe. This is not inconsistent with the fact that smaller firms perceive infrastructure to be a greater relative constraint. There may be structural reasons-such as larger firms' greater demands on various business climate dimensions - leading larger firms, on average, to report higher absolute constraint rankings in the various categories.

6. Transport is considered a severe constraint in only a handful of poor or war-torn economies, as well as in Ireland. Telecommunications is not perceived as a significant constraint, possibly indicating the extent to which the rapid spread of cellphones has resolved most communications problems. This underlines the need to update the survey questionnaire which until now refers to "mainline" telephone services only.

7. The other indicators may also capture some additional variation from unobserved variables. In essence, this means that there may still be some omitted variable bias that distorts the estimated parameters, or alternatively there may be no bias but the included variable may only be a proxy for the actual cause of the productivity effect.

8. The marginal impact of power outage duration on productivity could be much higher after a certain threshold, which may not be reached in middle-income countries.

9. Africa (10), South Asia (5), East Asia (7), Latin America and the Caribbean (7), OECD Europe (6), Central and Eastern Europe (8), South Eastern Europe (8), and the Commonwealth of Independent States (11).

10. South Africa is an exception: the constraints ranked most highly there are labor regulation, skill shortages, macroeconomic stability, and crime.

11. 'How problematic is financing for the operation and growth of your business: (1) no obstacle, (2) a minor obstacle, (3) a moderate obstacle or (4) a major obstacle?'

12. '(i) Are collateral requirements of bans/financial institutions no obstacle, a minor, a moderate or a major obstacle?; (ii) Is bank paperwork/bureaucracy no obstacle?; (iii) Are high interest 
rates no obstacle?; (iv) Is the need of special connections with banks/financial institutions no obstacle?; (v) Is banks' lack of money to lend no obstacle?; (vi) Is the access to foreign banks no obstacle?; (vii) Is the access to nonbank equity/investors/partners no obstacle?; (viii) Is the access to specialized export finance no obstacle?; (ix) Is the access to ease finance for equipment no obstacle?; (x) Is inadequate credit/financial information no obstacle?; (xi) Is the access to long term finance no obstacle?'

13. Except when the variable is entered separately from the other business climate variables, which renders it vulnerable to omitted variable bias.

14. Their variable is the city-industry share of the corruption score, which is constructed as the principal component of two variables: the ratio of bribes to sales plus the share of contract value used as a bribe to get a business contract.

\section{References}

Acemoglu, D., S. Johnson, and J.A. Robinson. 2001. "The Colonial Origins of Comparative Development: An Empirical Investigation.” American Economic Review 91(5): 1369-401.

Africa Infrastructure Country Diagnostic. 2010. Africa's Infrastructure: A Time for Transformation. www.infrastructureafrica.org, Washington, DC: World Bank.

Aghion, P., and R. Griffith. 2005. Competition and Growth: Reconciling Theory and Evidence; Cambridge, MA: MIT Press.

Alby, P., J.J. Dethier, and S. Straub. 2010. "Firms Operating under Infrastructure and Credit Constraints in Developing Countries. The Case of Power Generators." Paper presented at the International Conference on Infrastructure Economics and Development, Toulouse, January, (http:// econ.worldbank.org/conferences/icied).

Amin, M. 2007. “Labor Regulation and Employment in India’s Retail Stores.” Policy Research Paper 4314, World Bank, Washington.

Aschauer, D.A. 1989. “Is Public Expenditure Productive?” Journal of Monetary Economics 23(2): $177-200$.

Aterido, R., and M. Hallward-Driemeier. 2007. "Impact of Access to Finance, Corruption and Infrastructure on Employment Growth: Does Sub-Saharan Africa Mirror Other Low-Income Regions, " Policy Research Working Paper 5218. World Bank, Washington.

Aterido, R., M. Hallward-Driemeier, and C. Pagés. 2007. "Business Climate and Employment Growth: The Impact of Access to Finance, Corruption and Regulations Across Firms." Institute for the Study of Labor (IZA) Discussion Paper 3138, Bonn.

Ayyagari, Meghana, Asli Demirgüç-Kunt, and Vojislav Maksimovic. 2008. "How Important are Financing Constraints? The Role of Finance in the Business Environment." World Bank Economic Review 22I(3): 483-516.

Banerjee, A., and E. Duflo. 2005. "Growth Theory through the Lens of Development Economics." In A. Philippe, and S. Durlauf, eds., Handbook of Economic Growth. Amsterdam: North Holland: $473-552$.

Bartelsman, E., J. Haltiwanger, and S. Scarpetta. 2009. "Measuring and Analyzing Cross-Country Differences in Firm Dynamics.” In T. Dunne, J.B. Jensen, and M. Roberts, eds., Producer Dynamics: New Evidence from Micro Data. Chicago: University of Chicago Press.

Bastos, F., and J. Nasir. 2004. "Productivity and the Business climate: What Matters Most?" Policy Research Working Paper 3335. World Bank, Washington.

Beck, T., A. Demirgüç-Kunt, and V. Maksimovic. 2005. "Financial and Legal Constraints to Growth: Does Firm Size Matter?” The Journal of Finance LX(1): 137-77. 
Bertrand, M., and S. Mullainathan. 2001. "Do People Mean What They Say? Implications for Subjective Survey Data." The American Economic Review 91(2): 67-72.

Bigsten, A., and M. Söderbom. 2006. "What Have We Learned from a Decade of Manufacturing Enterprise Surveys in Africa?” The World Bank Research Observer 21(2): 241-65.

Calderón, C., E. Moral-Benito, and L. Servén. 2010. "Is Infrastructure Capital Productive? A Dynamic Heterogeneous Approach." Paper presented at the International Conference on Infrastructure Economics and Development, Toulouse, January. (http://econ.worldbank.org/ conferences/icied).

Carlin, W., M.E. Schaffer, and P. Seabright. 2006. "Where are the Real Bottlenecks? A Lagrangian Approach to Identifying Constraints on Growth from Subjective Survey Data." Discussion Paper 2006/04. Centre for Economic Reform and Transformation, Edinburgh.

Commander, S., and J. Svejnar. 2007. "Do Institutions, Ownership, Exporting and Competition Explain Firm Performance? Evidence from 26 Transition Countries." Institute for the Study of labor (IZA) Discussion Paper 2637, Bonn.

Datta, S. 2008. “The Impact of Improved Highways on Indian Firms” World Bank, Washington. (www.enterprisesurveys.org/ResearchPapers/).

Del Mel, S., D. McKenzie, and C. Woodruff. 2007. "Measuring Microenterprise Profits: Don’t Ask How the Sausage is Made." Policy Research Working Paper 4229. World Bank, Washington.

De Paula, A., and J. Sheinkman. 2008. “The Informal Sector.” Penn Institute for Economic Research Working Paper 08-018, Department of Economics, University of Pennsylvania.

Dollar, D., M. Hallward-Driemeier, and T. Mengistae. 2005. "Business Climate and Firm Performance in Developing Economies." Economic Development and Cultural Change 54:1-31.

2006. "Investment Climate and International Integration." World Development 34(9): $1498-516$.

Duflo, Esther, and R. Pande. 2007. "Dams.” The Quarterly Journal of Economics 122(1): 601-46.

Durlauf, S.N., A. Kourtellos, and C.M. Tan. 2008. "Are Any Growth Theories Robust?” The Economic Journal 118(527): 329-46.

Eifert, B., A. Gelb, and V. Ramachandran. 2008. "The Cost of Doing Business in Africa: Evidence from Enterprise Survey Data." World Development 36(9): 1531-46.

Escribano, A., and J.L. Guasch. 2005. "Assessing the Impact of the Business climate on Productivity Using Firm Level Data: Methodology and the Cases of Guatemala, Honduras, and Nicaragua." Policy Research Working Paper 3621. World Bank, Washington.

2008. "Robust Methodology for Business Climate Assessment on Productivity: Application to Business Climate Surveys From Central America.” Working Paper 08-19 (11). Universidad Carlos III de Madrid.

Escribano, A., J.L. Guasch, and J. Peña. 2010. "Assessing the Impact of Infrastructure Quality on Firm Productivity in Africa. Cross-Country Comparisons Based on Business climate Surveys from 1999 to 2005.” Policy Research Working Paper 5191. World Bank, Washington.

Fisman, R., and J. Svennson. 2007. "Are Corruption and Taxation Really Harmful to Growth? Firm Level Evidence." Journal of Development Economics 83:63-75.

Foster, V., and J. Steinbuks. 2009. "Paying the Price for Unreliable Power Supplies: In-house Generation of Electricity by Firms in Africa." Policy Research Working Paper Series 4913. World Bank, Washington.

Gelb, A., V. Ramachandran, M. Kedia-Shah, and G. Turner. 2007. "What Matters to African Firms? The Relevance of Perceptions Data.” Policy Research Working Paper 4446. World Bank, Washington. 
Gibson, J., and D. McKenzie. 2007. "Using Global Positioning Systems in Household Surveys for Better Economics and Better Policy." The World Bank Research Observer 22(2): 217-41.

Gibson, J., and S. Rozelle. 2003. "Poverty and Access to Roads in Papua New Guinea." Economic Development and Cultural Change 52:159-85.

Hall, R.E., and C.I. Jones. 1999. "Why Do Some Countries Produce So Much More Output per Worker than Others?" Quarterly Journal of Economics 114(1): 83-116.

Hallward-Driemeier, M., S. Wallsten, and L.C. Xu. 2006. "Ownership, Business Climate and Firm Performance: Evidence from Chinese Firms." Economics of Transition 14(4): 629-47.

Hausmann, R., and A. Velasco. 2005. "Slow Growth in Latin America: Common Outcomes, Common Causes?" (http://www.ricardohausmann.com/publications.php).

Honorati, M., and T. Mengistae. 2007. "Corruption, the Business Environment, and Small Business Growth in India.” Policy Research Working Paper 4338. World Bank, Washington.

Hsieh, C.T., and P. Klenow. 2009. "Misallocation and Manufacturing TFP in China and India." Quarterly Journal of Economics 124(4): 1403-48.

Katayama, H., S. Lu, and J. Tybout. 2009. "Firm-level Productivity Studies: Illusions and a Solution." International Journal of Industrial Organization 27:403-13.

Knack, S., and P. Keefer. 1995. "Institutions and Economic Performance: Cross-Country Tests Using Alternative Institutional Measures.” Economics \& Politics 7(3): 207-27.

Kruskal, W.H. 1987. "Relative Importance by Averaging over Orderings." The American Statistician 41:6-10.

Lee, K.S., and A. Anas. 1992. "Impacts of Infrastructure Deficiencies on Nigerian Manufacturing: Private Alternatives and Policy Options." Discussion Paper INU 98. Infrastructure and Urban Development Department, World Bank, Washington.

Lee, K.S., A. Anas, and G. Oh. 1996. "Cost of Infrastructure Deficiencies in Manufacturing in Indonesia, Nigeria and Thailand.” Policy Research Working Paper Series 1604. World Bank, Washington.

1999. "Costs of Infrastructure Deficiencies for Manufacturing in Nigerian, Indonesian and Thai Cities.” Urban Studies 36(12): 2135-49.

Mauro, P. 1995. “Corruption and Growth.” The Quarterly Journal of Economics 110(3): 681-712.

Miguel, E., P. Gertler, and D.I. Levine. 2005. "Does Social Capital Promote Industrialization? Evidence from a Rapid Industrializer." The Review of Economics and Statistics 87(4): 754-62.

Olken, B. 2009. "Corruption Perceptions vs. Corruption Reality." Journal of Public Economics 93(7-8): 950-64.

Pande, R., and C. Udry. 2005. "Institutions and Development: A View from Below.” Discussion Paper 928. Yale University Economic Growth Center.

Pierre, G., and S. Scarpetta. 2004. "Employment Regulations through the Eyes of Employers: Do They Matter and How Do Firms Respond to Them?" Institute for the Study of Labor (IZA) Discussion Paper 1424, Bonn.

Pritchett, L. 2000. "The Tyranny of Concepts: CUDIE (Cumulated, Depreciated, Investment Effort) Is Not Capital." Journal of Economic Growth 5(4): 361-84.

Rauch, J. 1991. "Modeling the Informal Sector Formally." Journal of Development Economics 35(1): $33-47$.

Romp, W., and J. de Haan. 2005. "Public Capital and Economic Growth: A Critical Survey." EIB Papers, 10(1): 40-70.

Straub, S. 2005. "Informal Sector: The Credit Market Channel." Journal of Development Economics 78(2): 299-321. 
2008. "Infrastructure and Growth in Developing Countries: Recent Advances and Research Challenges." Policy Research Working Paper 4460. World Bank, Washington.

Forthcoming. "Infrastructure and Development: A Critical Appraisal of the Macro-level Literature." Journal of Development Studies.

Straub, S., C. Vellutini, and M. Warlters. 2008. "Infrastructure and Economic Growth in East Asia." Policy Research Working Paper 4589. World Bank, Washington.

World Bank. 2004. World Development Report 2005: A Better Business Climate for Everyone. World Bank, Washington.

2008a. Financing for All? Policies and Pitfalls in Expanding Access. Policy Research Report. World Bank, Washington.

2008b. Thailand Investment Climate Assessment Update. Report 44248-TH. World Bank, Washington. 